\begin{tabular}{|c|c|c|}
\hline $\begin{array}{l}\text { EREM 73/1 } \\
\text { Journal of Environmental Research, }\end{array}$ & \multicolumn{2}{|c|}{$\begin{array}{l}\text { Modelling of the Potential Pattern and Concentration of Fugitive Dust } \\
\text { Around a Cement Plant }\end{array}$} \\
\hline $\begin{array}{l}\text { Vol. } 73 \text { / No. } 1 \text { / } 2017 \\
\text { pp. 48-58 }\end{array}$ & Received 2016/06 & Accepted after revision 2017/07 \\
\hline $\begin{array}{l}\text { DOI 10.5755/j01.erem.73.1.15398 } \\
\text { ๑ Kaunas University of Technology }\end{array}$ & \multicolumn{2}{|c|}{ Crossef http://dx.doi.org/10.5755/j01.erem.73.1.15398 } \\
\hline
\end{tabular}

\title{
Modelling of the Potential Pattern and Concentration of Fugitive Dust Around a Cement Plant
}

\section{Olanrewaju Lawal}

University of Port Harcourt, Faculty of Social Sciences, Department of Geography and Environmental Management P.M.B 5323, Choba Campus, Port Harcourt

\section{Aminanyanaba Onari Asimiea}

University of Port Harcourt, Faculty of Agriculture, Department of Crop and Soil Science

P.M.B 5323, Choba Campus, Port Harcourt

\section{Corresponding author: olalaw@hotmail.com}

Olanrewaju Lawal, University of Port Harcourt, Faculty of Social Sciences, Department of Geography and Environmental Management, P.M.B 5323, Choba Campus, Port Harcourt

Fugitive dust (FD) contributes to air pollution by its contribution to particulate matter (PM) in the air. FD comes from various sources, one of which is cement production. With this understanding, it is important to know the concentration of FD in the environment. Obajana Cement Plant is one of the recent cement production outfits in Nigeria. With many parts of the country having no air quality-monitoring infrastructure, it is thus important to use advances in modelling to understand the potential areas of impact of the plant. Using Gaussian plume modelling in combination with the geostatistical technique, this study examined potential distribution FD, exposure index and population at risk to PM exposure. Two major prevailing atmospheric stability condition maximums of $59 \mu \mathrm{g} / \mathrm{m}^{3}$ and $78 \mu \mathrm{g} / \mathrm{m}^{3}$ were obtained in June/July and December/January, respectively. Using empirical Bayesian kriging (EBK), most places across the State have concentrations between $20 \mu \mathrm{g} / \mathrm{m}^{3}$ and $38 \mu \mathrm{g} / \mathrm{m}^{3}$ for the July/June condition and between $33 \mu \mathrm{g} / \mathrm{m}^{3}$ and $50 \mu \mathrm{g} / \mathrm{m}^{3}$ in the December/ January condition. The probability of exceeding $15 \mu \mathrm{g} / \mathrm{m}^{3} \mathrm{com}$ - 
putation showed that more than $98 \%$ of the area had a $>60 \%$ chance of exceeding this threshold over the two periods. The average exposure index shows that about $23 \%$ of the population are exposed to concentrations below $25 \mu \mathrm{g} / \mathrm{m}^{3}$, while about $28 \%$ are exposed to concentrations about $35 \mu \mathrm{g} / \mathrm{m}^{3}$. There is a clear indication that there is a need to review the threshold of $250 \mathrm{\mu g} / \mathrm{m}^{3}$ set by the regulatory agencies as modelling with values lower than this still creates a significant amount of FD impact across vast areas of the State.

Keywords: fugitive dust, Gaussian plume model, geostatistical analysis, Obajana Cement Plant, empirical Bayesian kriging.

\section{Introduction}

Small particles of a geological origin that are suspended in the atmosphere and released through non-ducted emitters can be referred to as fugitive dust (Watson, Chow, and Pace, 2000). They have been found to contribute to air pollution. They could come from various sources, such as paved and unpaved roads, agriculture and open fields, construction sites as well as some industries (e.g., cement production, quarrying, mining and other solid mineral exploration). Plumes of FD may be noticed across these areas when there is sufficient wind speed or action to drive them. Particulate matter (and FD) with relevance for public health include those with an aerodynamic diameter less than $10 \mu \mathrm{m}\left(\mathrm{PM}_{10}\right)$ and $2.5 \mu \mathrm{m}\left(\mathrm{PM}_{2.5}\right)$. Across different parts of the world, different sources contribute differently to total fugitive dust emission. For example, in the USA, Watson et al. (2000) reported that unpaved roads (41.3\%), wind erosion (17.9\%), crop production (14.7\%) and construction activities (13.5\%) are the largest contributors to $\mathrm{PM}_{10} \mathrm{FD}$ total per year. For $\mathrm{PM}_{2.5}$, the largest contributors include unpaved roads $(33.7 \%)$, crop production (16\%), construction activities (15.6\%), wind erosion (14.5\%) and paved road. Thus, the evidence shows that at different particle sizes, different sources are important; however, some major sources are important across all the particle sizes. Furthermore, the authors reported that cement production accounted for about $0.5 \%$ of the total fugitive dust emission for $\mathrm{PM}_{10}$ and about $2.6 \%$ of the total for $\mathrm{PM}_{2.5}$. This is, however, not surprising since during the production of cement a significant amount of dust could be generated across every stage of the production - from quarrying down to packaging and dispatch.

The impacts of these particles have been widely reported across different parts of the world, especially $\mathrm{PM}_{25}$, which has been reported to have serious health implica- tions, such as pulmonary and cardiovascular problems, a negative impact on host defence mechanisms, cancer, low birth weight and infant mortality (Bhattacharjee et al., 1999, Pope III, Ezzati, and Dockery, 2009). Furthermore, these microscopic particles serve as binding surfaces for various other chemicals which, when inhaled, cause various respiratory diseases as they are inhaled deeply into the lungs (Berg and Hager, 2009). It is especially very important across urban areas (human settlements) due to persistently high PM concentrations, the number of people exposed, as well as the possibility of delayed effects (Romieu et al., 2012).

Spread and concentration of FD vary spatially depending on the nature and intensity of the sources, topography and weather conditions. Branquinho et al. (2008) reported that the nature of the dust as well as the volume and frequency of precipitation influence dust deposition around a cement mill. Watson et al. (2000) reported that FD emission is dependent on the size of the particles, topology, surface condition (soil/land surface), wind speed, surface moisture and the dust-suspending activities within the environment.

The traditional approach of examining transport of pollutants (contaminants) in the atmosphere is divided into two stages, namely (1) the estimation of the plume rise and (2) the estimation of dispersion of the plume after the plume has reached a maximum height. Understanding of this transport and estimates of FD emission is important in design, application and evaluation of control measures, which are meant to reduce FD emission. Since its commissioning in 2007, there has been no evaluation to assess the distribution of FD from the cement plant across the potential area of impact. However, a number of works have examined the impact of dust from the plant, including examination of 
haematological parameters of factory workers, metal accumulation in plants around the plant (Emmanuel, Ibiam, Okaka, and Alabi, 2015, Kabiru, Rufai, Lukman, and Fatima, 2015), impact of dust on stream sediment (Ameh, Kolawole, and Imeokparia, 2011), heavy metal accumulation in nearby stream (Okorie and Olorunfemi, 2015) and natural radioactivity health assessment (Isinkaye, Jibiri, and Olomide, 2015). In the light of these studies, the present research examined the spatial pattern of distribution of FD from Obajana Cement Plant. The aim of this study was to predict the potential distribution of FD emission from Obajana Cement Plant, using a combination of the Gaussian plume air dispersion model and the geostatistical technique, thereby creating a spatially explicit model for evaluation of potential impacts of the plant's operation on the surrounding environment.

\section{Materials and method}

\section{The study area}

The project is located near the Obajana community in Lokoja Local Government Area, which is about $25 \mathrm{ki}-$ lometres from Lokoja on the Kabba road, off the Lokoja-Okene road (Figure 1). The site is located within the co-ordinates E $006^{\circ} 25.225^{\prime} \mathrm{N} 07^{\circ} 55.488$ and E $006^{\circ}$ $25.837 \mathrm{~N} 07^{0} 55.906$. At the time of the establishment of the cement plant, Obajana was a rural community without any form of industrial establishment and minimal commercial activities. Other communities around Obajana are about 7-10 km away from Obajana; these include Oyo-Iwa, Apapta and Oshokoshoko. However, due to the population growth (across the country) and the pull effect of the plant, some changes in the growth of settlements across the area are bound to occur.

The climate of the area is characterized by distinct wet and dry seasons. The west season falls between April and October. The dry season runs from November to March. The average rainfall is about 1,200 $\mathrm{mm}$. The area falls within the Guinea Savannah type vegetation, which is characterized by low scattered trees and shrubs to tall grasses.

The topography of the project area is undulating (Figure 2). The highland areas are defined by hills in the form of ridges, with a north-south attitude. The terrain is very rugged with quartzite ridges, sometimes rising as high as 100 meters above the lowlands. The line stone deposit exists in the bed of the River Mimi, and to the east are quartz-muscovite-schist ridges. The highest elevation is in the north-eastern part of the area, which is above 310 meters above the sea level while the southern part has the lowest elevation of 255 meters above the sea level. The area is drained mainly by the River Mimi and its tributary, which forms a dendritic pattern of drainage and discharges its water southwards into the River Niger.

Fig. 1

Obajana Cement Plant location relative to Kogi State and other States in Nigeria

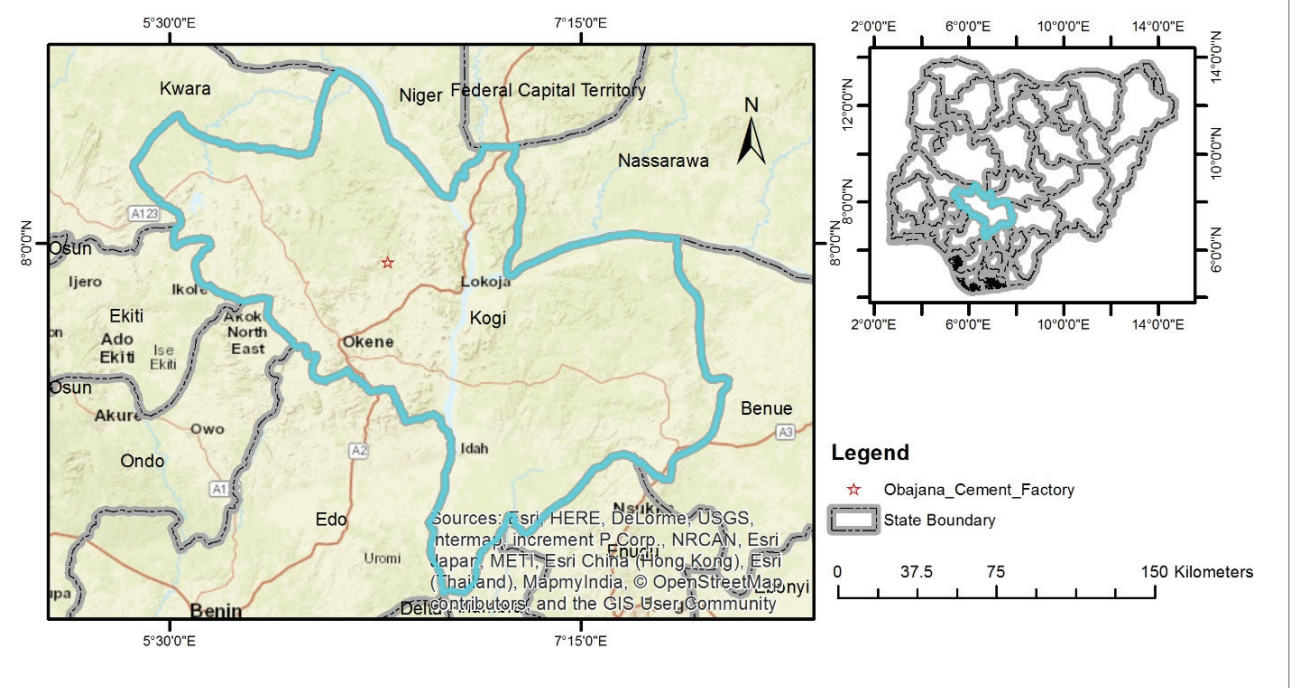




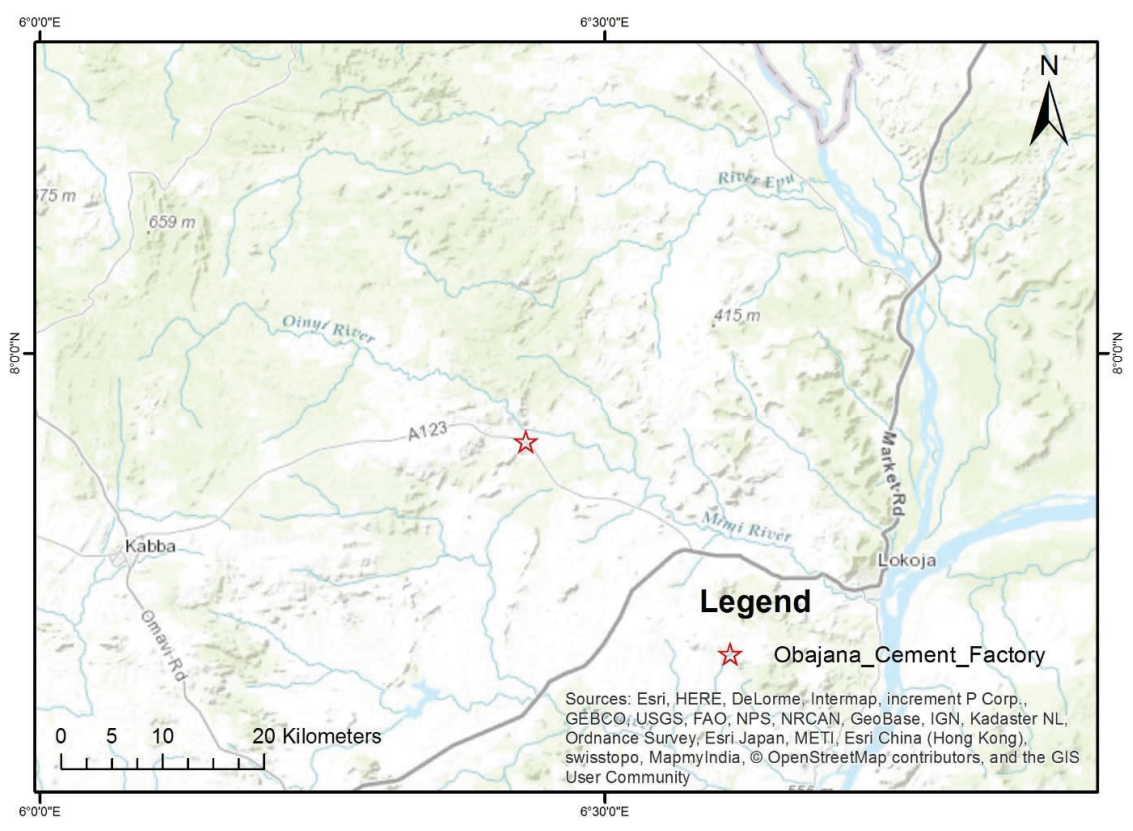

Fig. 2

Topographic condition of the study area and its environs

\section{Method}

\section{Characteristics of climatic condition}

Information on temperature, rainfall and relative humidity as well as prevailing wind speed and direction records were obtained from the Federal Department of Meteorology for the Lokoja station, which is the closest meteorological station to Obajana. Figures for June/ July and December/January were computed to obtain the two major wind directions for the location.

Temperature, rainfall and relative humidity indicate that the climate of Obajana has two clearly defined seasons, the long dry season, which starts at the end of October and ends in March, and the rainy season, which lasts between the months of April and September. During the rainy season, the wettest months in Obajana are between June and September. Obajana lies within the dry equatorial climatic region of Nigeria. It is generally warm, with the average daily temperature of about $30^{\circ} \mathrm{C}$ and the mean daily minimum of $27.5^{\circ} \mathrm{C}$. The hottest times of the year are in the months of February and March, with daytime temperatures reaching up to $35^{\circ} \mathrm{C}$. This is the period preceding the onset of the minor rains. The mean daily temperature during this time is above $34.0^{\circ} \mathrm{C}$. The months of July and August are relatively cool with the mean temperatures of $28.5^{\circ} \mathrm{C}$.

The highest values for relative humidity are usually recorded between the months of April and November, and the trend coincides with the duration of high rainfall. However, the relatively high values for the month of November are a result of the high moisture content of the soil at this time. It has also been observed that the rivers in the area, most of which are seasonal, overflow their banks between the months of October and November.

Wind speed generally ranges between 3.0 to 4.6 knots in the months of June/July with an exceptionally high average for June 2000 (14.0 knots, which coincides with an El Niño year). Wind speed for the months of December and January ranges from 1.5 to 3.7 knots. The prevailing wind directions between the months of June and July and the months of December and January are south-westerly and north-easterly, respectively.

\section{Mathematical modelling}

The traditional approach of examining transport of pollutants (contaminants) in the atmosphere is divided into two stages, namely (1) the estimation of the plume rise 
and (2) the estimation of dispersion of the plume after the plume has reached a maximum height. The dust released into the atmosphere is modelled to give the concentration at various functional conditions - wind speed, distance travelled, and effective stack height. Following Peirce, Weiner and Vesilind (1998) and on the basis of a Gaussian distribution, the concentration of pollutants in a plume traveling along the direction of the wind is given by:

$$
c(x, y, z)=\frac{Q}{2 \pi} \exp \left[-\frac{1}{2}\left(\frac{y}{\sigma_{y}}\right)^{2}\right] *\left\{\exp \left[-\frac{1}{2}\left(\frac{z-H}{\sigma_{z}}\right)^{2}\right]+\exp \left[-\frac{1}{2}\left(\frac{z+H}{\sigma_{z}}\right)^{2}\right]\right\}
$$

where

$c=$ concentration of pollutants at coordinates $x, y, z$ $\left(\mathrm{mg} / \mathrm{m}^{3}\right) ; Q=$ rate of emission of pollutants $(\mathrm{mg} / \mathrm{sec})$; $\sigma_{y}, \sigma_{z}=$ horizontal (cross wind) and vertical standard deviations of pollutant concentration along the centre line of plume (i.e. dispersion coefficient) $(\mathrm{m}) ; u=$ mean wind velocity $(\mathrm{m} / \mathrm{sec}) ; x=$ downwind distance along the centre line of the plume $(\mathrm{m}) ; y=$ horizontal distance from the centre line of the plume $(\mathrm{m}) ; z=$ vertical distance from the centre line of the plume $(\mathrm{m}) ; \mathrm{H}=$ effective plume height $(\mathrm{m})$.

The greatest value of the pollutant concentration is measured from the ground level $(z=0)$ and at the plume centre line $(y=0)$. Hence, the concentration in Equation (1) reduces to:

$$
c(x, y=0, z=0)=\frac{Q}{\pi \sigma_{y} \sigma_{z} u} \exp \left[-\frac{1}{2}\left(\frac{H}{\sigma_{z}}\right)^{2}\right] .
$$

This equation was implemented within the $\mathrm{R}$ programming language (version 3.1.0). The modelling operation covered the entire Kogi State (host state of the plant), and random points were created covering the entire State. A total of 6,300 random points were created covering the 21 local government areas of the State. A distance matrix was then constructed to compute the distance between the plant and each of these random points. This, thus, constitutes the input data for the $\mathrm{R}$ script for modelling the FD concentration.

\section{Empirical Bayesian kriging}

Kriging is an optimal spatial prediction (error minimisation technique), which has seen extensive use across various disciplines. It is a probabilistic predictor with a standard error which highlights the uncertainty associated with the prediction (Krige, 1951). Kriging has been reported to have (a) smaller uncertainty than other models, (b) better ability to filter measurement error, and (c) ability to use correlation among the input variables (Krivoruchko, 2012). Statistically, kriging assumes that there is spatial homogeneity; therefore, the data mean and the semivariogram (half the average squared difference of the values of all pairs of the data at locations separated by a given distance) are also the same. With this assumption the implication, therefore, is that few kriging models are required to get an optimal prediction and make valid inferences. However, this does not hold when data distribution is not Gaussian. Empirical Bayesian kriging (EBK) is improved on this shortcoming by:

1 estimating the semivariogram model from the data;

2 simulating a new data value (for each location) from this semivariogram;

3 estimating a new semivariogram from the simulated values, then using the Bayes rule, weights for the semivariogram are then calculated, thereby giving an indication probability of the observed data being generated from this semivariogram (Krivoruchko, 2012).

This, thus, creates a range of semivariograms, which is an estimate of the real semivariogram of the process that created the observed data. These formed the basis for the creation of the weights used for the prediction and prediction standard errors at unsampled locations. EBK was adapted for smoothing the regional epidemiological data by Berke (2004). The result shows that the interpolation is related to the internal standardization in epidemiology and the outcomes are better than choropleth maps. Bayesian kriging has also be found to be useful in the monitoring of the Nuclear Test Ban Treaty, thereby improving the monitoring of low level events and places with sparse monitoring stations (Myers and Schultz, 2000). On the interpolation of the spatio-temporal pattern of precipitation (monsoon period) over Pakistan, Hussain, Spöck, Pilz, and Yu (2010) compared transformed and non-transformed Bayesian Kriging method. 


\section{Result and discussion}

\section{Model assumptions}

Using the modelling approach highlighted above, FD emission was modelled for June/July and December/ January. In addition to this, a number of assumptions were made:

1 Modelling for June/July used atmospheric stability of $\mathrm{B}-\mathrm{C}$ (moderate incoming radiation) with an average wind speed of $3.6 \mathrm{~m} / \mathrm{s}$, while for December/January, atmospheric stability of $\mathrm{C}$ (moderate incoming radiation) with an average wind speed of $2.7 \mathrm{~m} / \mathrm{s}$ was adopted.

2 Plume height was modelled within the range between 5 and 30 meters.

3 A maximum of 3 stacks was assumed.

4 Source strength per stack was set at $50 \mathrm{mg} / \mathrm{s}$.

5 In computing the plume standard deviations, Alpha (neutral horizontal dispersion coefficient) of 0.008 was assumed and Beta (neutral vertical dispersion coefficient) of 0.006 was assumed.

6 Initial ground level concentration of FD was set to $2 \mathrm{mg} / \mathrm{m}^{3}$.

\section{Spatial distribution across the atmospheric stability conditions}

As based on the assumption stated above, the results from the initial Gaussian plume dispersion model are presented in Table 1. Considering the vast area under investigation, there is a similarly wide variation in the values for FD deposited at different locations as captured in the standard deviation (raging between $17 \mu \mathrm{g} /$ $\mathrm{m}^{3}$ and $23 \mu \mathrm{g} / \mathrm{m}^{3}$ ). Across the entire area, the average FD deposited is between $27 \mu \mathrm{g} / \mathrm{m}^{3}$ and $36 \mu \mathrm{g} / \mathrm{m}^{3}$. The maximum values obtained range between $59 \mu \mathrm{g} / \mathrm{m}^{3}$ and $78 \mu \mathrm{g} / \mathrm{m}^{3}$ with the December/ January stability con- dition having higher values all across. These estimates are also in line with the environmental condition during the time of the year when the condition is dry and when this current output is combined with the dust from the dry season and Harmattan; there could be a significant health risk. However, in modelling with all the earlier stated assumptions, the FD emission from the cement plant site was not above the $250 \mu \mathrm{g} / \mathrm{m}^{3}$ standard set by the Federal Ministry of Environment (FMENV).

Values for the 6,300 points were subjected to EBK interpolation to create a spatially explicit model of FD emission from the source across Kogi State. This creates a spatial distribution of the FD emission, which could be used to support planning and mitigation measures.

The output from the geostatistical analysis for the June/July period is presented in Figures $3 a$ and $b$, and that of December/January is presented in Figures $4 a$ and $b$. For the June/July period, the modelling output shows that the distribution had a range of $0.0-58.68 \mathrm{\mu g} / \mathrm{m}^{3}$, the root mean square error stood at around $17.64 \mu \mathrm{g} / \mathrm{m}^{3}$, while the average standard error was around $17.75 \mu \mathrm{g} / \mathrm{m}^{3}$. This prediction map (Figure 3a) shows that the majority of the places across the State have FD ranges between $20 \mu \mathrm{g} / \mathrm{mg}^{3}$ and $38 \mu \mathrm{g} / \mathrm{mg}^{3}$; however, the prediction error ranges between $4 \mu \mathrm{g} / \mathrm{mg}^{3}$ and $13 \mu \mathrm{g} / \mathrm{mg}^{3}$ across the State. Moreover, high values of FD could also be found further away from the cement plant. It must be noted that this is assuming equal wind speed and direction across the area.

In spite of this, there is a clear evidence to suggest that FD from the plant could influence the FD level as far away as 155 kilometres (approximate distance of the farthest point from the plant within the State); however, the prediction for such a distance also shows a very high standard error (Figure 3b).

For the December/January period, the range for modelled FD was found to be higher (Figure 4a) with the

\begin{tabular}{c|c|c|c|c|c|c}
\hline \multirow{2}{*}{$\begin{array}{c}\text { Time/stability } \\
\text { condition }\end{array}$} & $\begin{array}{c}\text { Maximum } \\
\left(\mu \mathrm{g} / \mathrm{m}^{3}\right)\end{array}$ & Mean $\left(\mu \mathrm{g} / \mathrm{m}^{3}\right)$ & $\begin{array}{c}\text { Standard devia- } \\
\text { tion }\left(\mu \mathrm{g} / \mathrm{m}^{3}\right)\end{array}$ & \multicolumn{3}{|c|}{ Distance from sources $(\mathrm{km})$} \\
\cline { 5 - 6 } & 2 & 3 & 4 & 5 & 6 & 7 \\
\hline 1 & 58.685 & 26.710 & 16.927 & & \\
\hline June/ July & 78.247 & 35.614 & 22.569 & 80.73 & 170.66 & 0.53 \\
\hline December/ January & & & & & \\
\hline
\end{tabular}

Table 1

Summary of Gaussian plume dispersion modelling 
Fig. 3

EBK geostatistical modelling for PM from Obajana Cement Plant during June/ July period

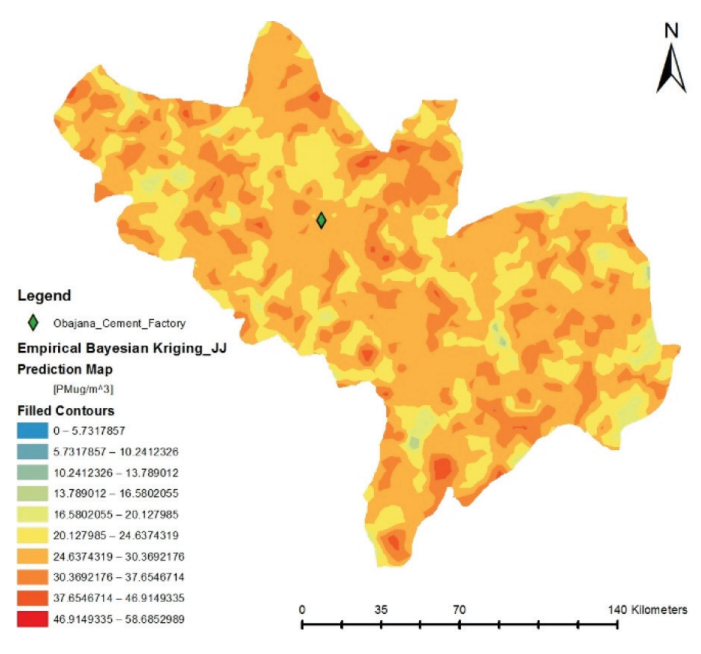

a

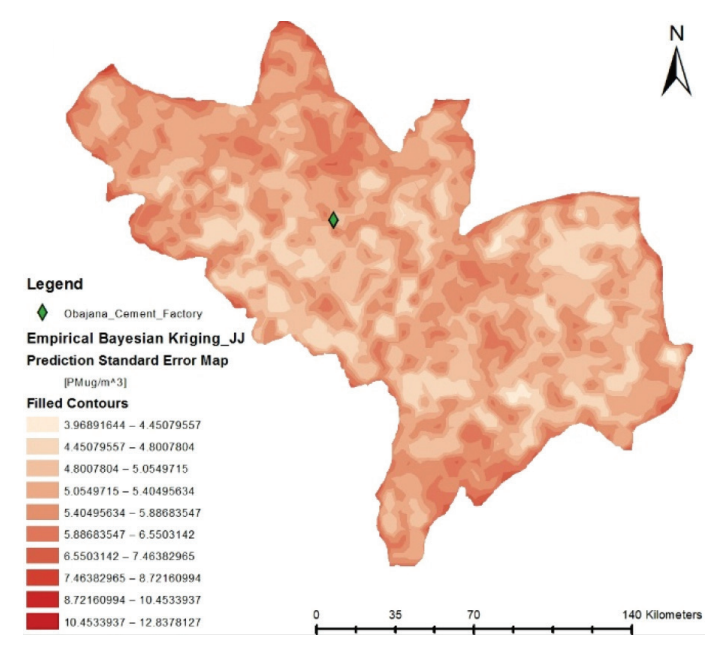

b

Fig. 4

EBK modelling output for FD during the December/ January period

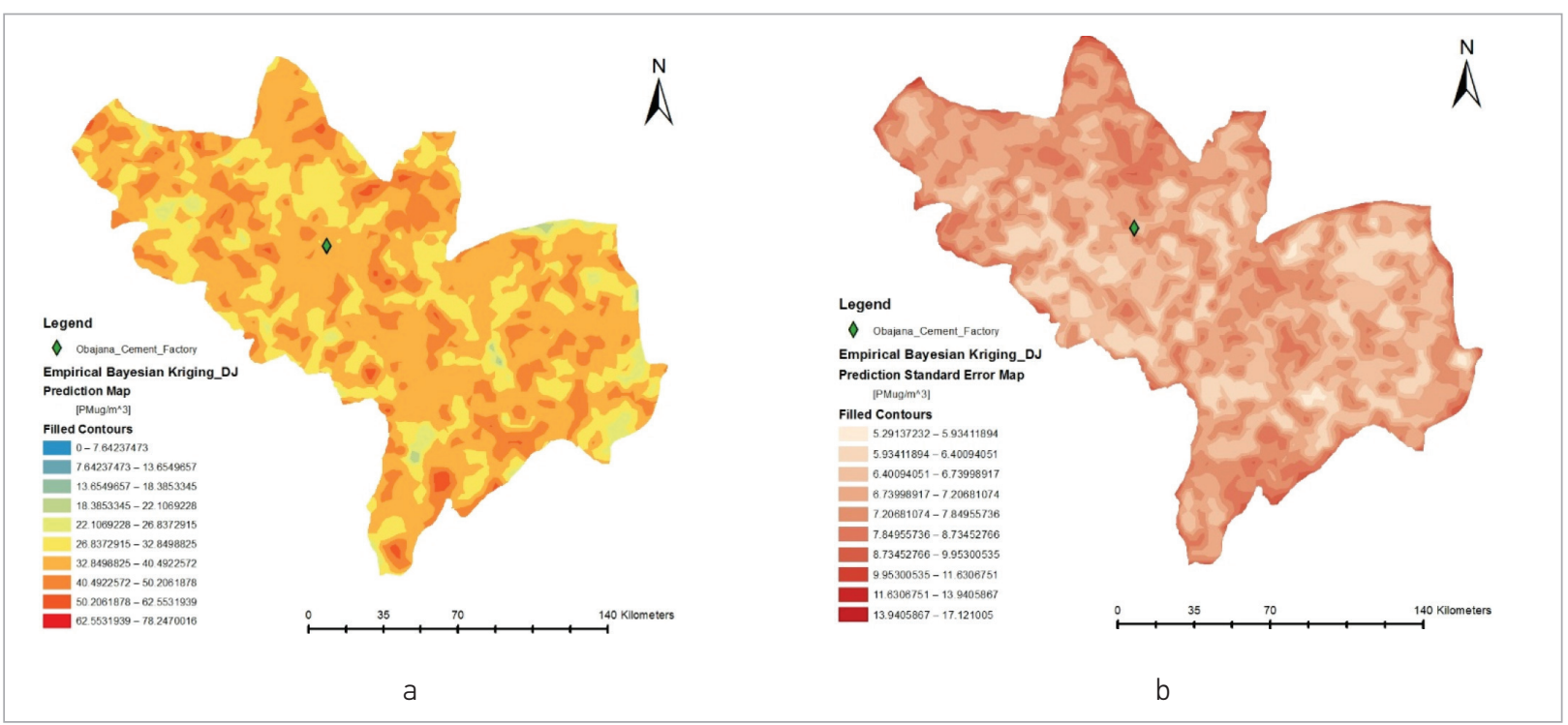

maximum value of about $78 \mu \mathrm{g} / \mathrm{m}^{3}$, and the pattern of distribution is similar to that obtained for the June/ July period. The difference is only in the values, e.g., most of the locations fell within the range of $33 \mu \mathrm{g} / \mathrm{m}^{3}$ and $50 \mu \mathrm{g} / \mathrm{m}^{3}$. Furthermore, the standard error of the prediction was also found to be highest at the furthest dis- tance from the plant. The root mean square error stood at around $23.52 \mu \mathrm{g} / \mathrm{m}^{3}$, while the average standard error was around $23.66 \mu \mathrm{g} / \mathrm{m}^{3}$.

Across the two periods considered, the RMS errors and the average standard errors were high, but the standardized RMS was close to 1 (which shows that the predic- 
tion was fairly accurate). However, in order to facilitate communication of the modelling output, the probability of exceedance was also computed to capture the uncertainty, which can be attributed to this modelling exercise. A standard of annual average of $15 \mu \mathrm{g} / \mathrm{m}^{3}$ (average of $10 \mu \mathrm{g} / \mathrm{m}^{3}$ for $\mathrm{PM}_{2.5}$ and $20 \mu \mathrm{g} / \mathrm{m}^{3}$ for $\mathrm{PM}_{10}$ from the WHO (2014)) was used to construct the probability map for the two periods. The result shows that about $98 \%$ of the entire study area had a high probability (> 60\% probability) of having an FD concentration about $15 \mu \mathrm{g} / \mathrm{m}^{3}$ in June/July, while almost the entire surface (99.8\%) had a high probability in the December/ January period. Moreover, a medium probability was also obtained for about $1.6 \%$ of the area during the June/ July period.

\section{Table 2}

Percentage area and probability of exceeding $15 \mu \mathrm{g} / \mathrm{m} 3$ across the study area

\begin{tabular}{c|c|c}
\hline \multirow{2}{*}{ Probability class } & \multicolumn{2}{|c}{ Percentage of total area } \\
\cline { 2 - 3 } & Dec./Jan. & June/July \\
\hline 1 & 2 & 3 \\
\hline Low (<40\%) & $0.03 \%$ & $0.39 \%$ \\
\hline Medium (40-60\%) & $0.22 \%$ & $1.58 \%$ \\
\hline High (> 60\%) & $99.76 \%$ & $98.04 \%$ \\
\hline
\end{tabular}

From the foregoing results, there is a clear indication that it is pertinent to devise mitigation measures to reduce the FD/PM in the ambient air. The situation becomes even more precarious to human health when we consider that particulate matter has been implicated in pulmonary and cardiovascular problems and other public health issues mentioned earlier. With this high coverage and high probability, it is important to further streamline the results to learn how this area matches up with human habitation, thereby providing insight into the exposure and the population at risk.

\section{Population at risk and average exposure index}

The population data used for this study area were collated for 2014 and sourced from Worldpop Datasets (www.worldpop.org.uk). This dataset is based on UN Alpha Estimates and computed using the methods described by Linard, Gilbert, Snow, Noor and Tatem (2012). For each of the two periods, the total population above different levels of FD concentrations were computed.
Spatial query generated five maps of different FD concentrations, identifying areas with FD concentration $>10,>15,>25$ and $>35 \mu \mathrm{g} / \mathrm{m}^{3}$, which were extracted from the two model output maps (January/December and June/July). A risk indicator of average exposure was computed to illustrate the population at each level of FD exposure. The result (Table 3 ) shows that at the average combined concentration of $15 \mu \mathrm{g} / \mathrm{m}^{3}$ almost every part of the entire population of the study area is at risk for both periods. For $<10 \mu \mathrm{g} / \mathrm{m}^{3}$, just about $0.01 \%$ (out of $4,241,647$ people) of the population is not at risk of exposure to this concentration of FD for these two periods. In the case of $>25 \mu \mathrm{g} / \mathrm{m}^{3}$, about $61 \%$ and $94 \%$ of the population were at risk for June/July and December/ January, respectively. At $>35 \mu \mathrm{g} / \mathrm{m}^{3}$, there is a wide variation between the population at risk across the two periods, and the same was also observed for $>25 \mu \mathrm{g} / \mathrm{m}^{3}$. These variations could be attributed to the atmospheric stability condition, whereby there is a lower stability under the condition observed in June/July as opposed to the more stable condition observed in December/January. This further highlights the importance of atmospheric stability in the distribution of pollutant across the landscape. Thus, a slight variation in the average wind speed $(0.9 \mathrm{~m} / \mathrm{s})$ over the area (with all other factors being the same) was able to create a very considerable difference (between 33\% and 45\%) in the total number of people exposed to FD above $25 \mu \mathrm{g} / \mathrm{m}^{3}$.

Regarding the average exposure computed as the average percentage of the population exposed to a certain level of FD (Table 3), the result shows that about 0.26\% of the total population (of the State) live in areas with FD dust below $15 \mu \mathrm{g} / \mathrm{m}^{3}$, while about $23 \%$ of the population

\section{Table 3}

Population at risk and average exposure to different FD levels

\begin{tabular}{c|c|c|c}
\hline \multirow{2}{*}{$\begin{array}{c}\text { FD classes } \\
\left(\mu \mathrm{g} / \mathrm{m}^{3}\right)\end{array}$} & \multicolumn{2}{|c|}{ Percentage population by period } & \multirow{2}{*}{$\begin{array}{c}\text { Average } \\
\text { exposure }\end{array}$} \\
\cline { 2 - 3 } & December/January & June/July & \\
\hline 1 & 2 & 3 & 4 \\
\hline$>10$ & $100.00 \%$ & $99.99 \%$ & $99.99 \%$ \\
\hline$>15$ & $99.95 \%$ & $99.53 \%$ & $99.74 \%$ \\
\hline$>35$ & $94.01 \%$ & $60.61 \%$ & $77.31 \%$ \\
\hline
\end{tabular}


live in areas below $25 \mu \mathrm{g} / \mathrm{m}^{3}$. Above $35 \mu \mathrm{g} / \mathrm{m}^{3}$, there are about $28 \%$ of the total population of Kogi State in this area. With such statistics, it is no wonder that the WHO (2014) estimated that about $88 \%$ of the 3.7 million premature deaths globally occurred as a result of ambient air quality (in rural and urban areas) in lower and middle income countries. There is no doubt that despite industrial development like Obajana Cement Plant, most of the FD spread in Kogi State is due to unpaved roads, which generated more FD in December/ January.

Across the two periods, the proportion of the population living within or below the combined WHO average of the standard is very low $(<1 \%$ of the total population). The average exposure figures show that there is a considerable public health risk for most of the population. With the current estimate of the population at about 4.2 million and the average exposure above $35 \mathrm{\mu g} / \mathrm{m}^{3}$, there are over 1 million people exposed to very poor quality ambient air. From the foregoing, it is evident that with the conservative figures (i.e., 3 stacks of $5-30$ meters high, $50 \mathrm{mg} / \mathrm{s}$ source strength, neutral plume dispersion characteristics and ground level FD concentration of $2 \mathrm{mg} / \mathrm{m}^{3}$ ), FD across the study area can reach levels well above recommended standards. It should also be noted that the modelled emission from the cement plant is still within the limit specified by the FMENV.

Across the two main atmospheric stability conditions, the average FD concentration was highest in December/ January, which coincides with the dry season, and Harmattan, which essentially brings more dust to the West African region. The implication, therefore, is that the condition is likely to be even worse during this period. For the two stability conditions, estimates of FD concentration across the study area are still well above the combined average of $15 \mu \mathrm{g} / \mathrm{m}^{3}$. While the source strength modelled never reached the FMENV limit, the emission was still enough to create high levels of FD across the study area, which could constitute a serious public health issue.

Geostatistical analysis using EBK shows that with prediction errors around $4 \mu \mathrm{g} / \mathrm{m}^{3}$ and $17 \mu \mathrm{g} / \mathrm{m}^{3}$, estimates of FD concentration range between $0 \mu \mathrm{g} / \mathrm{m}^{3}$ and $78 \mu \mathrm{g} /$ $\mathrm{m}^{3}$. Moreover, there is a clear indication that FD emission from the cement plant has a considerable influence on the location well away from the plant (most locations have values between $20 \mu \mathrm{g} / \mathrm{mg}^{3}$ and $38 \mu \mathrm{g} / \mathrm{mg}^{3}$ in June/ July and between $33 \mu \mathrm{g} / \mathrm{m}^{3}$ and $50 \mu \mathrm{g} / \mathrm{m}^{3}$ in December/ January). The comparison of the model results to the WHO combined standard shows that about 98\% (June/July) and $99.8 \%$ (December/January) of the study area have more than $60 \%$ probability of FD above $15 \mu \mathrm{g} / \mathrm{m}^{3}$. The probability computation, thus, highlights the potential exposure of the entire study area, and the result gives a clear indication that there is a high probability of exposure to FD concentration that is dangerous to human health.

Matching the population with that of modelled FD concentration allows estimating the population at risk of exposure to high level of FD concentration. The results clearly show that the majority of the population are exposed to a high level FD concentration even when conservative assumptions are considered.

\section{Conclusions}

FD refers to small particles of a geological origin, suspended in the atmosphere and released through non-ducted emitters. FD and most significantly PM have been implicated in having negative effects on pulmonary and cardiovascular systems, host defence mechanisms, cancer, low birth weight and infant mortality (Bhattacharjee et al., 1999, Pope III et al., 2009). Such impacts are usually more pronounced in urban areas with high concentration of people and possible delayed effects (Romieu et al., 2012). FD comes from various sources, such as paved and unpaved roads, agriculture and open fields, construction sites as well as some industries (e.g., cement production, quarrying, mining and other solid mineral exploration). Across many developing countries, there is often sparse and non-representative monitoring of outdoor air quality (Gutierrez, 2010), which leaves a huge data gap. This often hampers planning and proper policy making as there is a need for development of methods that could fill this gap. Geospatial analysis and modelling approaches offer an opportunity to generate insights that could support decision-making. This study examined the spread and distribution of FD from Obajana Cement Plant in Kogi State, using a combination of the Gaussian plume model and geostatistical analysis.

On the basis of very conservative assumptions, it could be concluded that the level of FD across the study area had a high probability of exceeding $15 \mu \mathrm{g} / \mathrm{m}^{3}$. This was clear when the exceedance probability was computed for two atmospheric stability conditions considered. Furthermore, there was a high level of FD concentra- 
tion, which coincided with the Harmattan period, and this could further aggravate public health concerns of PM exposure across the study area.

The modelling approach offers a rapid assessment opportunity for examining the potential impact of an emission source or factories across any region, especially in a situation where not all the information is available or it is expensive to obtain. By using the prediction errors as well as probability maps, it is possible to inform decision makers of the uncertainty associated with the modelling output.

On the basis of the modelling output and the assumptions made, it is possible to conclude that there is a need for the review of the FMENV standard. This is relevant because even with the conservative assumptions of emission, the FD concentration across vast areas of the study still shows a high level (well above the WHO standard) even after accounting for the prediction and

\section{References}

Ameh, E. G., Kolawole, M. S., \& Imeokparia, E. G. (2011). Using factor-cluster analysis and enrichment methods to evaluate impact of cement production on stream sediments around Obajana cement factory in Kogi state, North Central Nigeria. Advances in Applied Science Research, 2(1), 76-89.

Berke, 0. (2004). Exploratory disease mapping: kriging the spatial risk function from regional count data. International Journal of Health Geographics, 3(1), 1. https://doi.org/10.1186/1476072X-3-18

Bhattacharjee, H., Drescher, M., Good, T., Hartley, Z., Leza, J.-D., Lin, B., ... Wu, D. (1999). Particulate Matter in New Jersey. In D. Kammen, T. Holloway \& D. Murillo (Eds.), WWS 589: Methods in Science, Technology, and Public Policy. New Jersey: Woodrow Wilson School of Public and International Affairs, Princeton University. Branquinho, C., Gaio-Oliveira, G., Augusto, S., Pinho, P., Máguas, C., \& Correia, O. (2008). Biomonitoring spatial and temporal impact of atmospheric dust from a cement industry. Environmental Pollution, 151(2), 292-299. doi: http://dx.doi.org/10.1016/j. envpol.2007.06.014 https://doi.org/10.1016/j.envpol.2007.06.014

Emmanuel, T. F., Ibiam, U. A., Okaka, A. N. C., \& Alabi, O. J. (2015). Effects of cement dust on the hematological parameters in Obajana cement factory workers. European Scientific Journal, 11(27). Gutierrez, E. (2010). Using satellite imagery to measure the relationship between air quality and infant mortality: an empirical study for Mexico. Population and Environment, 31(4), 203-222. doi: 10.1007/ s11111-009-0096-y. https://doi.org/10.1007/s111111-009-0096-y standard error. It is also clear that high FD concentrations are not only limited to nearby locations. With the potential for a delayed effect on human health, it is important that effort and initiatives should commence to review the standard set by the FMENV. The modelled output clearly shows that there is a significant amount of work to be done by the authorities to ensure good air quality across many parts of the country (Lawal and Asimiea, 2015). The cement plant was reported to have a capacity of 5 million tonnes in 2007 and new capacities are being added to take the production to about 13 million metric tonnes (Emmanuel et al., 2015). With this understanding, it is clear that there is potential for more emission from this facility; therefore, effort needs to be made to ensure that FD concentrations are not increasing proportionally as capacity increases. Therefore, there is a need for continuous monitoring and evaluation of activities with an important public health implication across the country.

Hussain, I., Spöck, G., Pilz, J., \& Yu, H.-L. (2010). Spatio-temporal interpolation of precipitation during monsoon periods in Pakistan. Advances in water resources, 33(8), 880-886. https:// doi.org/10.1016/j.advwatres.2010.04.018

Isinkaye, O. M., Jibiri, N. N., \& Olomide, A. A. (2015). Radiological health assessment of natural radioactivity in the vicinity of Obajana cement factory, North Central Nigeria. Journal of Medical Physics / Association of Medical Physicists of India, 40(1), 52-59. doi: 10.4103/0971-6203.152256. https://doi. org/10.4103/0971-6203.152256

Kabiru, S., Rufai, Y., Lukman, A., \& Fatima, M. (2015). Effects of Cement Kiln Dust On Some Selected Plants Around Obajana Cement Factory. Journal Of Chemical Society Of Nigeria (jcsn), 40.

Krige, D. (1951). A Statistical Approach to Some Basic Mine Valuation Problems on the Witwatersrand. Journal of the Chemical, Metallurgical and Mining Society of South Africa, 52(6), 119139. doi: citeulike-article-id:3070804

Krivoruchko, K. (2012). Empirical bayesian kriging. Retrieved February, 12, 2016, from http://www.esri.com/news/arcuser/1012/empirical-byesian-kriging.html

Lawal, O., \& Asimiea, A. O. (2015). Spatial modelling of population at risk and PM 2.5 exposure index: A case study of Nigeria. Ethiopian Journal of Environmental Studies and Management, 8(1), 69-80. https://doi.org/10.4314/ejesm.v8i1.7

Linard, C., Gilbert, M., Snow, R. W., Noor, A. M., \& Tatem, A. J. (2012). Population Distribution, Settlement Patterns and Accessibility 
across Africa in 2010. PLoS ONE, 7(2), e31743. doi: 10.1371/journal.pone.0031743. https://doi.org/10.1371/journal.pone.0031743

Myers, S. C., \& Schultz, C. A. (2000). Improving Sparse Network Seismic Location with Bayesian Kriging and Teleseismically Constrained Calibration Events. Bulletin of the Seismological Society of America, 90(1), 199-211. doi: 10.1785/0119980171 https://doi. org/10.1785/0119980171

Okorie, E., \& Olorunfemi, C. I. (2015). Monitoring the distribution of cadmium in sediment samples from Obajana stream in North central Nigeria. International Journal of Biological and Chemical Sciences, 8(4), 1948-1954. https://doi.org/10.4314/ijbcs.v8i4.54

Peirce, J. J., Weiner, R. F., \& Vesilind, P. A. (1998). Chapter 19 Meteorology and Air Pollution Environmental Pollution and Control (Fourth Edition) (pp. 271-286). Woburn: Butterworth-Heine- mann. https://doi.org/10.1016/B978-075069899-3/50020-1

Pope III, C. A., Ezzati, M., \& Dockery, D. W. (2009). Fine-particulate air pollution and life expectancy in the United States. New England Journal of Medicine, 360(4), 376-386. https://doi. org/10.1056/NEJMsa0805646

Romieu, I., Gouveia, N., Cifuentes, L. A., de Leon, A. P., Junger, W., Vera, J., . . Tzintzun-Cervantes, G. (2012). Multicity study of air pollution and mortality in Latin America (the ESCALA study). Res Rep Health Eff Inst(171), 5-86.

Watson, J. G., Chow, J. C., \& Pace, T. G. (2000). Fugitive dust emissions.

WHO. (2014). Ambient (outdoor) air quality and health. Fact Sheets. Retrieved from Ambient (outdoor) air quality and health website: http://www.who.int/mediacentre/factsheets/fs313/en/

\section{Dulkètumo požymių ir koncentracijų modeliavimas aplink cemento gamyklos teritoriją}

\section{Olanrewaju Lawal}

Port Harcourt universitetas, Socialinių mokslų fakultetas, Geografijos ir aplinkos vadybos katedra, Nigerija

\section{Aminanyanaba Onari Asimiea}

Port Harcourt universitetas, Žemės ūkio fakultetas, Dirvožemio katedra, Nigerija

Dulkès didina kietuju dalelių koncentracija ore ir taip žymiai prisideda prie aplinkos taršos. Vienas iš dulkių emisiju šaltiniu yra cemento gamyba. Norint kontroliuoti dulketumą, svarbu nustatyti ir žinoti dulkių koncetraciją aplinkoje. Obajana cemento gamykla yra viena iš neseniai veikiančių cemento gamyklų Nigerijoje. Kadangi daugelyje šalies vietų nèra oro kokybės stebejjimo infrastruktūros, todèl svarbu, pasitelkiant modeliavimą prognozuoti i̇monés veiklos poveiki potencialiose teritorijose.

Šiame tyrime, naudojant Gauso pasiskirstymo modeli (ang. Gaussian plume models) kartu su geostatiniu metodu, nagrinejamas galimas kietuju daleliu pasiskirstymas, kietuju dalelių ekspozicijos indeksas tos teritorijos gyventojams. Esant stabilioms atmosferos sąlygoms birželio/liepos ir gruodžio/sausio menesiais kietuju daleliu koncentracija pasieke maksimumus $59 \mu \mathrm{g} / \mathrm{m}^{3}$ ir $78 \mu \mathrm{g} / \mathrm{m}^{3}$ atitinkamai. Naudojant empirini Bajeso Kriging (EBK) metodą, daugelyje vietu visoje valstybèje buvo nustatyta koncentracija nuo $20 \mu \mathrm{g} / \mathrm{m}^{3} \mathrm{iki} 38 \mu \mathrm{g} / \mathrm{m}^{3}$ birželio ir liepos mèn., o nuo gruodžio ir sausio mènesiais - nuo $33 \mu \mathrm{g} / \mathrm{m}^{3} \mathrm{iki} 50 \mu \mathrm{g} /$ $\mathrm{m}^{3}$. Tikimybiniai skaičiavimai parodè, kad daugiau nei $98 \%$ tiriamos teritorijos turejo daugiau kaip $60 \%$ tikimybę viršyti $15 \mu \mathrm{g} / \mathrm{m}^{3}$ koncentracijos slenksti per tiriamus du laikotarpius.

Vidutinis ekspozicijos indeksas rodo, kad apie $23 \%$ gyventoju susiduria su kietuju dalelių koncentracijomis, mažesnèmis nei $25 \mathrm{\mu g} \mathrm{m}^{3}$, o apie $28 \%$ gyventoju susiduria su koncentracija, kuri yra apie $35 \mu \mathrm{g} / \mathrm{m}^{3}$. Tyrimai rodo aišku požymi, jog reikalinga persvarstyti reguliavimo agentūros nustatytą kietuju daleliu koncentracijos $250 \mu \mathrm{g} / \mathrm{m}^{3}$ slenksti, nes modeliavimas rodo, kad ir žemesnès koncentracijos sukelia reikšmingą dulkètumo poveiki valstybès teritorijoje.

Raktiniai žodžiai: dulkètumas, Gauso plumio modelis, geostatistinè analizè, Obajana cemento gamykla, empirinis Bajeso Krigingo metodas 


\begin{tabular}{|c|c|c|}
\hline \multirow{3}{*}{$\begin{array}{l}\text { EREM 73/1 } \\
\text { Journal of Environmental Research, } \\
\text { Engineering and Management } \\
\text { Vol. } 73 \text { / No. } 1 \text { / } 2017 \\
\text { pp. 59-69 } \\
\text { DOl 10.5755/j01.erem.73.1.14149 } \\
\text { @ Kaunas University of Technology }\end{array}$} & \multicolumn{2}{|c|}{$\begin{array}{l}\text { Effect of Magnetic Treatment of Water on Chemical Properties of } \\
\text { Water and the Lifespan of the Effect }\end{array}$} \\
\hline & Received 2016/02 & Accepted after revision 2017/07 \\
\hline & \multicolumn{2}{|c|}{ crossef http://dx.doi.org/10.5755/j01.erem.73.1.14149 } \\
\hline
\end{tabular}

\title{
Effect of Magnetic Treatment of Water on Chemical Properties of Water and the Lifespan of the Effect
}

\author{
Ayodele Olanrewaju Ogunlela, Kamorudeen Olaniyi Yusuf \\ University of Ilorin, Department of Agricultural and Biosystems Engineering, Nigeria
}

Corresponding author: yusuf.ok@unilorin.edu.ng

Kamorudeen Olaniyi Yusuf, University of Ilorin, Department of Agricultural and Biosystems Engineering, Nigeria

This study was conducted to determine the effect of treating water by the magnetic field on chemical properties of water, sodium adsorption ratio (SAR), electrical conductivity (EC) of water and the lifespan of the effect on water. Magnetic flux densities used as the treatments in this study were 124, 319, 443 and $719 \mathrm{G}$ measured inside a rectangular plastic glass pipe. The mean values of concentration of calcium for magnetically treated water (MTW) for days 1, 2, 3 and 4 after the treatment were 3.197, 3.166, 3.136 and $3.104 \mathrm{mg} / \mathrm{L}$, while those of non-magnetically treated water (NMTW) were 3.130, 3.095, 3.055 and $3.020 \mathrm{mg} / \mathrm{L}$, respectively. The mean values of nitrate from MTW were $43.07,43.04,42.71$ and $42.56 \mathrm{mg} / \mathrm{L}$, while those of NMTW were $42.73,42.57,42.00$ and $41.81 \mathrm{mg} / \mathrm{L}$, respectively. The mean value of sulphate from MTW on day 1 was $50.06 \mathrm{mg} / \mathrm{L}$, while that of NMTW was $47.80 \mathrm{mg} / \mathrm{L}$. The mean values of SAR from NMTW were all higher than the values from MTW. The values of EC were also higher for non-magnetically treated water than the values from treated water. Magnetically treated water is better for irrigating soil than non-magnetically treated water that could cause soil salinity.

Keywords: irrigation water quality, magnetic treatment of water, magnetized water, magnetically treated water, sodium adsorption ratio.

\section{Introduction}

Magnetic treatment of water is a non-chemical method for crop improvement and prevention of carbonate deposition in the pipe. The technology is new in Nigeria and there is a need for research on the effect of magnetic treatment of water on the chemical properties of water and its applications in the society. Magnetic fields actu- 
ally change the structure of water thereby reducing the surface tension of water, soften water, increase mineral dissolvability of water and hence provide adequate nutrients for plant growth (Babu, 2010). When water passes through the magnetic field, its structure and some physical characteristic such as density, salt solution capacity, and deposition ratio of solid particles will be changed (Higashitani et al., 1993). Noran et al. (1996) pointed out that the results of their work confirmed the assumption that as a result of the influence of the magnetic field on solutes, the interaction between soil particles and salts dissolved in ordinary water did not resemble the interaction between soil particles and salts dissolved in magnetically treated water. Kochmarsky (1996) indicated that the effective magnetic flux density for water treatment ranged from 1,000 to $6,000 \mathrm{G}$. He also pointed out that 4,000 to $5,000 \mathrm{G}$ could attain the efficiency of 60 to $80 \%$ when applied on heater and low-pressure boilers. Mdsa'at (2006) and Chern (2012) used a permanent magnet with magnetic field strength of $5,500 \mathrm{G}$ to treat water which was used to irrigate lady's finger moench plant, and the effect on plant growth and yield was significant. Maheshwari and Grewal (2009) monitored and recorded magnetic flux densities inside the treatment pipe where the actual treatment occurs and the values of magnetic field strength obtained ranging from 35 to $1,360 \mathrm{G}$.

The objectives of this study were as follows: 1 ) to determine the effect of magnetic treatment of water on concentration of chemical properties of water; 2) to determine the effect of magnetic treatment of water sodium adsorption ratio and electrical conductivity of water; and 3) to determine the lifespan of the effect of magnetic treatment of water.

\section{Materials and methods}

The magnetic field used for the treatment of water in this study was produced from an electromagnet with variable voltage adjustment unit from 4 to $12 \mathrm{~V}$ to vary the current flowing through the coil. The magnetic flux densities used to treat water as the treatments were $124,319,443$ and $719 \mathrm{G}\left(\mathrm{T}_{1}, \mathrm{~T}_{2}, \mathrm{~T}_{3}\right.$ and $\left.\mathrm{T}_{4}\right)$, measured inside the transparent rectangular pipe (having an internal dimension of 1.5 by $4.6 \mathrm{~cm}$ and $100 \mathrm{~cm}$ long) using a Gauss meter.
The north and south poles of electromagnetic cores on the treatment chamber seat were alternated for effective treatment of water by the magnetic field (McMahon, 2009). Water was allowed to pass through the treatment chamber units four (4) times for duration of 83-113 s using the circulation flowing method through the magnetic field (Mdsa'at, 2006, Chern, 2012). Two samples were taken from each treatment (magnetized water treated with 124, 319, 443, $719 \mathrm{G}$ and untreated water) and put in a cleaned bottle. The chemical properties of the water were determined on day 1 , day 2 , day 3 and day 4 after the water had been treated with the magnetic field. This was done to determine the effect of magnetic treatment of water on the chemical properties of water and its lifespan on the water.

High concentration of sodium in water is detrimental to soil as high sodium content in the body of a man induces high blood pressure (hypertension). The proportion of sodium to other cations (sodium hazard) is determined by sodium adsorption ratio (SAR). SAR of the water treated magnetic field was determined from Equation (1) as given by Schwab et al. (1993). Values of sodium, calcium and magnesium were obtained from Appendices 1 to 4 and the concentration was converted from $\mathrm{mg} / \mathrm{L}$ to meq/L using Equation (3), while Equation (2) was used to convert atomic mass of the element to an equivalent weight.

$$
S A R=\frac{N a^{*}}{\sqrt{\frac{C a^{2+}+M g^{2+}}{2}}} .
$$

$$
E_{\text {meq/l }}=\frac{E_{\text {conc. }}}{E_{\text {eq.wt }}} .
$$

$$
E_{\text {eq.wt }}=\frac{A_{\text {mass }}}{V_{\text {lency }}}
$$

where

SAR is sodium adsorption ratio ( $\mathrm{dS} / \mathrm{m}$ or $\mathrm{mmho} /$ $\mathrm{cm}) ; \mathrm{Na}^{+}$is the concentration of sodium in water 
(meq/L); $\mathrm{Ca}^{2+}$ is the concentration of calcium in water $(\mathrm{meq} / \mathrm{L}) ; \mathrm{Mg}^{2+}$ is the concentration of calcium in water (meq/L); $E_{\text {meq// }}$ is the concentration of a certain element in miliequivalent per litre (meq/L); $E_{\text {conc }}$ is the concentration of a certain element in water $(\mathrm{mg} / \mathrm{l})$; $E_{\text {eqwt }}$ is the equivalent weight of an element; $A_{\text {mass }}$ is the atomic mass of an element and $V_{\text {lency }}$ is the valency of an element.

\section{Statistical analysis of chemical properties of water by paired $t$ test}

Statistical analysis of the chemical properties of water was conducted using the paired $t$ test method to check if the effect of magnetic treatment of water was statistically significant on water or not. The difference between the two means of the results was determined, which was used to compute standard deviation, standard error and t test value using Equations (4), (5a) or (5b), (6) and (7), respectively, as given by Montgomery et al. (1998).

$$
\bar{d}=\frac{\sum d}{n}
$$

$$
\delta=\sqrt{\frac{\sum(d-\bar{d})^{2}}{n-1}} .
$$

$$
\delta=\sqrt{\frac{\sum d^{2}-n(\bar{d})^{2}}{n-1}} .
$$

$$
\delta_{E r}=\frac{\delta}{\sqrt{n}} .
$$

$$
t_{c a l}=\frac{\bar{d}}{\delta_{E r}}
$$

where

$\bar{d}$ is the mean of the difference from the data $x_{1}$ and $x_{2} ; \Sigma d$ is the summation of $d ; n$ is the number of the treatments (observations); $\delta$ is the standard deviation; $\delta_{E r}$ is the standard error and $t_{c a l}$ is the calculated value of $t$, which was compared with the Table value of $t_{T a b}$ at $\alpha=5 \%$ significance level but $2.5 \%(\alpha=0.05 / 2=0.025)$ for the paired $t$ test.

\section{Results and Discussion}

The comprehensive results of water passed through the magnetic field with flux densities of $719,443,319$, $124 \mathrm{G}$ and non-magnetized water are shown in Appendices 1 to 4 , but the mean values of the chemical properties of water are shown in Table 1. The statistical

Table 1

Mean values of some chemical properties of water

\begin{tabular}{c|c|c|c|c|c|c|c|c|c|c|}
\hline \multirow{2}{*}{$\mathrm{S} /$ No } & \multirow{2}{*}{ Element } & \multirow{2}{*}{ Unit } & \multicolumn{4}{|c|}{ Magnetically treated water } & \multicolumn{4}{c}{ Non-magnetically treated water } \\
\cline { 5 - 13 } & & & Day 1 & Day 2 & Day 3 & Day 4 & Day 1 & Day 2 & Day 3 & Day 4 \\
\hline 1 & 2 & 3 & 4 & 5 & 6 & 7 & 8 & 9 & 10 & 11 \\
\hline 1 & $\mathrm{Ca}^{+2}$ & $\mathrm{mg} / \mathrm{L}$ & 3.197 & 3.166 & 3.136 & 3.104 & 3.130 & 3.095 & 3.055 & 3.020 \\
\hline 2 & $\mathrm{Mg}^{+2}$ & $\mathrm{mg} / \mathrm{L}$ & 1.229 & 1.218 & 1.204 & 1.186 & 1.285 & 1.265 & 1.255 & 1.245 \\
\hline 3 & $\mathrm{~K}^{+}$ & $\mathrm{mg} / \mathrm{L}$ & 0.888 & 0.864 & 0.859 & 0.839 & 0.885 & 0.870 & 0.855 & 0.825 \\
\hline 4 & $\mathrm{Na}^{+}$ & $\mathrm{mg} / \mathrm{L}$ & 80.55 & 80.42 & 80.28 & 80.14 & 81.91 & 81.76 & 81.66 & 81.58 \\
\hline 5 & $\mathrm{NO}_{3}^{-}$ & $\mathrm{mg} / \mathrm{L}$ & 43.07 & 43.04 & 42.71 & 42.56 & 42.73 & 42.57 & 42.00 & 41.91 \\
\hline 6 & $\mathrm{SO}_{4}^{-2}$ & $\mathrm{mg} / \mathrm{L}$ & 50.06 & 49.67 & 49.24 & 48.66 & 47.80 & 47.67 & 47.50 & 43.38 \\
\hline 7 & $\mathrm{P}$ & $\mathrm{mg} / \mathrm{L}$ & 0.654 & 0.640 & 0.633 & 0.620 & 0.670 & 0.660 & 0.645 & 0.635 \\
\hline
\end{tabular}


analysis of the treatment on chemical properties of water determined on days 1, 2, 3 and 4 to know the lifespan (memory) of the effect on water after being treated by the magnetic field is shown in Table 2. The effect of magnetic treatment of water had more influence on the precipitation (concentration) of sulphate than other anions like nitrate. The values of sulphate $\left(\mathrm{SO}_{4}^{2-}\right)$ precipitation with magnetic water on day 1 were higher by 2.8 to $9.6 \%$ compared with the value for non-magnetic water which was in agreement with the result obtained by Mostazadeh (2011) that magnetic water increased the precipitation of sulphate in soil in comparison with non-magnetic water. The effect of the magnetic field slightly increased calcium precipitation compared with non-magnetic water by $0.6 \%$. This result also showed that water could be treated and used after some days ( 2 to 4 days) without losing much effect of the magnetic treatment.

\section{Table 2}

Statistical analysis of the magnetic field on chemical properties of water by pair paired $t$ test

\begin{tabular}{|c|c|c|c|c|c|c|}
\hline S/No & Parameter & Effect of magnetic field on & $\begin{array}{l}\text { Degree of } \\
\text { freedom }\end{array}$ & $\mathrm{t}_{\text {Cal }}$ & $\begin{array}{c}\mathrm{t}_{\mathrm{Tab}} \text { at } \alpha=0.05 \\
(\alpha / 2=0.025)\end{array}$ & Effect \\
\hline 1 & 2 & 3 & 4 & 5 & 6 & 7 \\
\hline \multirow{6}{*}{1} & Calcium & \multirow{6}{*}{$\begin{array}{l}\text { Chemicals concentration of } \\
\text { water between magnetic } \\
\text { and non-magnetic water }\end{array}$} & 3 & 1.810 & 3.182 & Not significant \\
\hline & Potassium & & 3 & 1.170 & 3.182 & Not significant \\
\hline & Sodium & & 3 & 7.530 & 3.182 & Significant \\
\hline & Nitrate & & 3 & 0.433 & 3.182 & Not significant \\
\hline & Sulphate & & 3 & 2.100 & 3.182 & Not significant \\
\hline & Lead & & 3 & 0.000 & 3.182 & Not significant \\
\hline \multicolumn{7}{|c|}{ Lifespan of magnetic treatment of water } \\
\hline \multirow{3}{*}{2} & \multirow{3}{*}{ Calcium } & Day 1 and 2 & 3 & 1.849 & 3.182 & Not significant \\
\hline & & Day 1 and 3 & 3 & 1.947 & 3.182 & Not significant \\
\hline & & Day 1 and 4 & 3 & 1.855 & 3.182 & Not significant \\
\hline \multirow{3}{*}{3} & \multirow{3}{*}{ Potassium } & Day 1 and 2 & 3 & 4.019 & 3.182 & Significant \\
\hline & & Day 1 and 3 & 3 & 4.600 & 3.182 & Significant \\
\hline & & Day 1 and 4 & 3 & 4.672 & 3.182 & Significant \\
\hline \multirow{3}{*}{4} & \multirow{3}{*}{ Sodium } & Day 1 and 2 & 3 & 2.778 & 3.182 & Not significant \\
\hline & & Day 1 and 3 & 3 & 6.696 & 3.182 & Significant \\
\hline & & Day 1 and 4 & 3 & 5.919 & 3.182 & Significant \\
\hline \multirow{3}{*}{5} & \multirow{3}{*}{ Nitrate } & Day 1 and 2 & 3 & 1.717 & 3.182 & Not significant \\
\hline & & Day 1 and 3 & 3 & 2.188 & 3.182 & Not significant \\
\hline & & Day 1 and 4 & 3 & 3.735 & 3.182 & Significant \\
\hline \multirow{3}{*}{6} & \multirow{3}{*}{ Sulphate } & Day 1 and 2 & 3 & 2.473 & 3.182 & Not significant \\
\hline & & Day 1 and 3 & 3 & 2.663 & 3.182 & Not significant \\
\hline & & Day 1 and 4 & 3 & 3.497 & 3.182 & Significant \\
\hline
\end{tabular}


The value of SAR in Table 3 varied from 9.367 to 9.994 $\mathrm{dS} / \mathrm{m}$ and the values were within the range of 1 to $10\left(\mathrm{~S}_{1}=\right.$ low value) according USDA 1954 (United States Department of Agriculture) as cited by Schwab et al. (1993). The values of SAR with high magnetic flux densities of 719 and $443 \mathrm{G}$ were higher than the values of SAR obtained with low flux densities of 319 and $124 \mathrm{G}$. This means that low magnetic flux density ranging from 124 to $319 \mathrm{G}$ was good for treating irrigation water in order to have a low value of SAR and consequently to have no or low effect of sodium on soil. Again, the values of SAR also increased from day 1 to day 4 as shown in Table 3. The difference between SAR of magnetically treated water and SAR of non-magnetically treated water was not statistically significant with the calculated value of the paired $t$ test $\left(t_{\text {cal }}\right) 1.957$, which was less than the Table value of t test at the $5 \%$ significance level $(\alpha=0.05$, but paired $t$ test $=\alpha / 2=0.025$ ).

The values of electrical conductivity were higher on day 1 for both magnetically and non-magnetically treated water but they decreased with days. The values were also within the low $\left(\mathrm{C}_{1}\right)$ class, which cannot cause adverse effect on soil as shown in Table 4. The effect of

Table 3

Values of sodium adsorption ratio (SAR) of the water used

\begin{tabular}{|c|c|c|c|c|c|c|c|c|}
\hline \multirow{2}{*}{ Treatment } & \multicolumn{4}{|c|}{ Magnetic water SAR (dS/m) } & \multicolumn{4}{|c|}{ Non-magnetic water SAR (dS/m) } \\
\hline & Day 1 & Day 2 & Day 3 & Day 4 & Day 1 & Day 2 & Day 3 & Day 4 \\
\hline 1 & 2 & 3 & 4 & 5 & 6 & 7 & 8 & 9 \\
\hline $\mathrm{T}_{1}$ & 9.897 & 9.919 & 9.905 & 9.562 & 9.877 & 9.920 & 9.948 & 9.976 \\
\hline $\mathrm{T}_{2}$ & 9.933 & 9.965 & 9.971 & 9.994 & 9.877 & 9.901 & 9.948 & 9.976 \\
\hline $\mathrm{T}_{3}$ & 9.583 & 9.587 & 9.616 & 9.662 & 9.877 & 9.901 & 9.948 & 9.976 \\
\hline $\mathrm{T}_{4}$ & 9.447 & 9.367 & 9.582 & 9.655 & 9.877 & 9.901 & 9.948 & 9.976 \\
\hline Mean & 9.715 & 9.710 & 9.769 & 9.718 & 9.877 & 9.906 & 9.948 & 9.976 \\
\hline USDA standard for SAR (dS/m) & \multicolumn{2}{|c|}{$0-10^{\mathrm{s} 1}$} & \multicolumn{2}{|c|}{$10-18^{s 2}$} & \multicolumn{2}{|c|}{$18-26^{\mathrm{s}}$} & \multicolumn{2}{|c|}{$26-30^{54}$} \\
\hline
\end{tabular}

$S_{1}$ - Class 1 - low value without effect on soil, $S_{2}$ - Class 2 - medium no effect, $S_{3}$ - Class 3 - high with little effect, and $S_{4}$ - Class 4 - very high with serious effect on soil. SAR - sodium adsorption ratio and USDA - United States Department of Agriculture

\section{Table 4}

Values of electrical conductivity (EC) of the water used

\begin{tabular}{|c|c|c|c|c|c|c|c|c|}
\hline \multirow{2}{*}{ Treatment } & \multicolumn{4}{|c|}{ Magnetic water EC (dS/m) } & \multicolumn{4}{|c|}{ Non-magnetic water EC (dS/m) } \\
\hline & Day 1 & Day 2 & Day 3 & Day 4 & Day 1 & Day 2 & Day 3 & Day 4 \\
\hline 1 & 2 & 3 & 4 & 5 & 6 & 7 & 8 & 9 \\
\hline $\mathrm{T}_{1}$ & 0.1855 & 0.1650 & 0.1670 & 0.1710 & 0.1860 & 0.184 .5 & 0.1820 & 0.1795 \\
\hline $\mathrm{T}_{2}$ & 0.1825 & 0.1695 & 0.1650 & 0.1580 & 0.1860 & 0.184 .5 & 0.1820 & 0.1795 \\
\hline $\mathrm{T}_{3}$ & 0.1865 & 0.1810 & 0.1815 & 0.1745 & 0.1860 & 0.184 .5 & 0.1820 & 0.1795 \\
\hline $\mathrm{T}_{4}$ & 0.1770 & 0.1750 & 0.1735 & 0.1715 & 0.1860 & 0.184 .5 & 0.1820 & 0.1795 \\
\hline Mean & 0.1829 & 0.1726 & 0.1718 & 0.1688 & 0.1860 & 0.1840 & 0.1820 & 0.1795 \\
\hline USDA standard for EC (dS/m) & \multicolumn{2}{|c|}{$0.1-0.25^{\mathrm{cl}}$} & \multicolumn{2}{|c|}{$0.25-0.75^{\mathrm{c} 2}$} & \multicolumn{2}{|c|}{$0.75-2.25^{c 3}$} & \multicolumn{2}{|c|}{$>2.25^{\mathrm{C4}}$} \\
\hline
\end{tabular}

$C_{1}$ - Class 1 - low value without effect on soil, $C_{2}$ - Class 2 - medium no effect, $C_{3}$ - Class 3 - high with little effect, and $C_{4}-$ Class 4 - very high with serious effect on soil. EC - Electrical conductivity and USDA - United States Department of Agriculture 
the magnetic field caused a reduction in electrical conductivity of the water. The difference between the electrical conductivity $(\mathrm{EC})$ of magnetically treated water and non-magnetically treated water was statistically significant with $t_{\text {cal }} 3.521$, which was greater than the Table value $\left.\left(t_{T a b}\right) 3.182\right)$ at the $5 \%$ significance level. The values of SAR and EC of magnetically treated water and non-magnetically treated water over the period

\section{Fig. 1}

Sodium adsorption ratio of the water from University of Ilorin dam

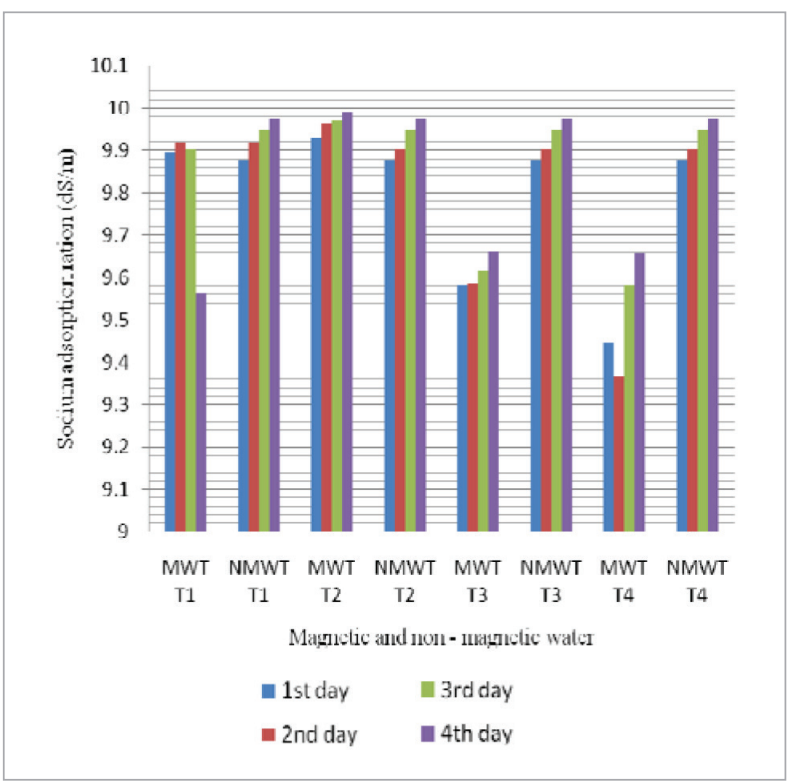

\section{Conclusions}

Magnetic treatment of water had effect on chemical properties of water by increasing the rate of precipitation of cations and the lifespan of the effect of magnetic treatment of water could last for four days on some chemical properties of water. The mean values of concentration of calcium for magnetically treated water (MTW) for days 1, 2, 3 and 4 after the treatment were $3.197,3.166,3.136$ and $3.104 \mathrm{mg} / \mathrm{L}$, while those of non-magnetically treated water (NMTW) were $3.130,3.095,3.055$ and $3.020 \mathrm{mg} / \mathrm{L}$, respectively. The mean values of nitrate from MTW were 43.07, $43.04,42.71$ and $42.56 \mathrm{mg} / \mathrm{L}$, while those of NMTW of 4 days after being treated with magnetic field are shown in Figures 1 and 2.

MWT - magnetized water, NMWT - non-magnetized water, T1 - magnetized water treated with $719 \mathrm{G}, \mathrm{T} 2$ water treated with $443 \mathrm{G}, \mathrm{T} 3$ - water treated with $319 \mathrm{G}$, and $\mathrm{T} 4$ - with $124 \mathrm{G}$.

MWT, NMWT, T1, T2, T3 and T4 are as defined in Figure 1.

Fig. 2

Electrical conductivity of the water from University of Ilorin dam

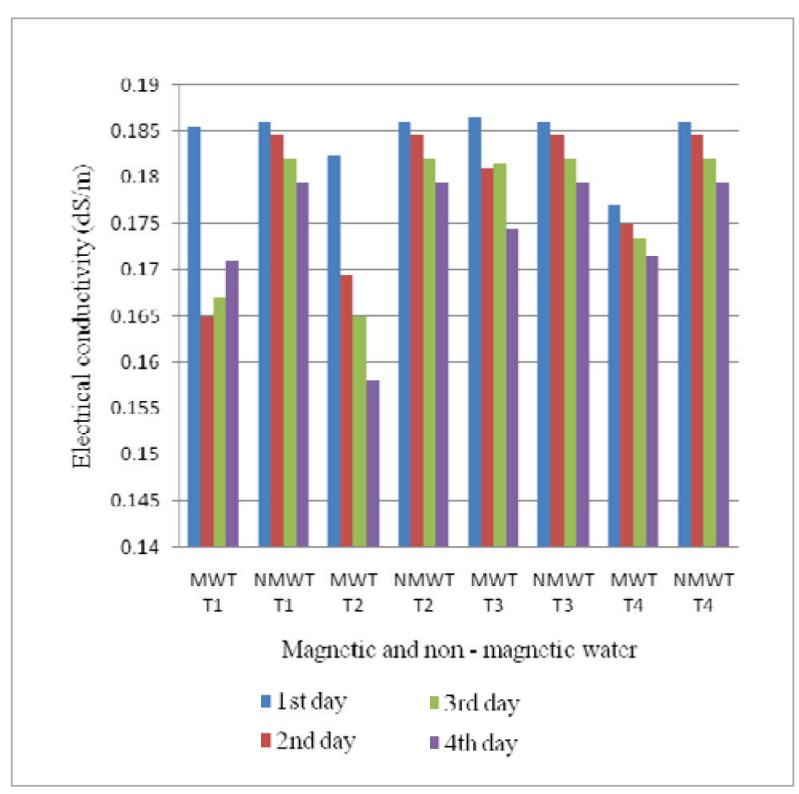

were $42.73,42.57,42.00$ and $41.81 \mathrm{mg} / \mathrm{L}$, respectively. The mean value of sulphate from MTW on day 1 was $50.06 \mathrm{mg} / \mathrm{L}$, while that of NMTW was $47.80 \mathrm{mg} / \mathrm{L}$. The mean values of SAR from NMTW were all higher than the values from MTW. The values of EC were also higher for non-magnetically treated water than the values from treated water. Magnetically treated water is better for irrigating soil than non-magnetically treated water that could cause soil salinity. Magnetic flux densities of 124, 319, 443 and $719 \mathrm{G}$ inside the treatment pipe were appropriate for magnetic treatment of water. 


\section{References}

Anand, A., Nagarajan, S., Verma, A. P. S., Joshi, D. K., Pathak, P. C. and Bhardwaj, J (2012). Pre - treatment of seeds with static magnetic field ameliorates soil water stress in seedling of maize (Zea mays L.), Indian Journal of Biochemistry and Biophysics, 49 (1): 63 - 70.

Babu, C. (2010) Use of magnetic water and polymer in agriculture. Tropical Research, ID 08 - 806-001.

Chern, C. C. (2012) Application of magnetic water to stimulate the lady's finger (Abelmosculentus L.) moench

Chineke, T.C., Idinoba, M.E and Ajayi, O.C (2011) Seasonal ET signatures under a changing land scope and

El - Sayed, H. and Sayed A. (2014) Impact of magnetic water irrigation for improve the growth, chemical composition and yield production of broad bean (Vicia faba L.) Plant. American Journal of Experimental Agriculture, 4(4): 476-496. https:// doi.org/10.9734/AJEA/2014/7468

Gabrielli, C., Jaouhari, R., Maurin, G.and Keddam, M (2000) Magnetic water treatment for scale prevention,

Higashitani K., A. Kage, S. Katamura, K. Imai, S. Hatade, (1993). Effects of a magnetic field on the formation of $\mathrm{CaCO} 3$ particles. Colloid and Interface Science.1993, 156(1):90-95. https://doi.org/10.1006/jcis.1993.1085

Hozayn, M. and Abdul- Qados, A. M. S.(2010) Irrigation with magnetized water enhances growth, chemical constituent and yield of chickpea (Circer arietinum L.). Agriculture and Biology Journal of North America, 1(4): 671 - 676.

Kochmarsky, V. (1996) Magnetic treatment of water: possible mechanisms and conditions for applications. Magnetic and Electrical Separation, 7: 77-107. https://doi. org/10.1155/1996/89312
Kronenberg, K. J. (1985) Experimental evidence for effects of magnetic fields on moving water. IEEE Trans. on Magnetics, vol. Mag-21, no. 5: 2059-2061. https://doi.org/10.1109/ TMAG.1985.1064019

Maheshwari, R. L. and Grewal, H. S (2009) Magnetic treatment of irrigation water: its effects on vegetable crop yield and water productivity. Journal of Agricultural Water Management, 96 (8) :1229-1236. https://doi.org/10.1016/j.agwat.2009.03.016

McMahon, C. A. (2006) Investigation of the quality of water treated by magnetic fields. B. Eng. Thesis

Mdsa'at S. K. (2006) Subsurface flow and free water surface flow constructed wetland with magnetic field for

Montgomery, D. C., Runger, G. C., Hubele, N. F (1998) Engineering statistics. John Wiley and Sons, Inc, New York: 135 - 248.

Moussa, H. R. (2011) The impact of magnetic water application for improving common bean (Phaseolus vulgaris L.) production. New York Science Journal, 4(6): 15 - 20.

Noran, R., Shani, U and Lin, I. (1996) The effect of irrigation with magnetically treated water on the translocation of minerals in the soil. Magnetic and Electrical Separation, 7: 109-122. https://doi.org/10.1155/1996/46596

Schwab, G. O., Fangmeier, D. D, Elliot, W. J. and Frevert, R. K (1993) Soil and Water Conservation Engineering. 4th Edition, John Wiley and Sons, Inc, New York.

Podlesny, J., Pietruszewski, S. and Podleoena, A. (2004) Efficiency of the magnetic treatment of broad bean seeds cultivated under experimental plot conditions. Int. Agrophysics, 18: 65-7.

Suchitra, K. and Babu, E. A. (2011) A pilot study on silt magnetized and non-magnetized water in the on-farm water use efficiency management. Centre for Water Resources, Anna University, Chennai, India. 


\section{Appendix 1}

Chemical properties of water treated with $719 \mathrm{G}$ magnetic field

\begin{tabular}{|c|c|c|c|c|c|c|c|c|c|c|}
\hline \multirow{2}{*}{ S/No } & \multirow{2}{*}{ Element } & \multirow{2}{*}{ Unit } & \multicolumn{4}{|c|}{ Magnetic treated water } & \multicolumn{4}{|c|}{ Non-magnetic treated water } \\
\hline & & & Day 1 & Day 2 & Day 3 & Day 4 & Day 1 & Day 2 & Day 3 & Day 4 \\
\hline 1 & 2 & 3 & 4 & 5 & 6 & 7 & 8 & 9 & 10 & 11 \\
\hline 1 & $\mathrm{Ca}^{2+}$ & $\mathrm{mg} / \mathrm{L}$ & 3.150 & 3.135 & 3.140 & 3.125 & 3.130 & 3.095 & 3.055 & 3.020 \\
\hline 2 & $\mathrm{Mg}^{2+}$ & $\mathrm{mg} / \mathrm{L}$ & 1.125 & 1.115 & 1.105 & 1.100 & 1.285 & 1.265 & 1.255 & 1.245 \\
\hline 3 & $\mathrm{~K}^{+}$ & $\mathrm{mg} / \mathrm{L}$ & 0.905 & 0.890 & 0.890 & 0.885 & 0.885 & 0.870 & 0.855 & 0.825 \\
\hline 4 & $\mathrm{Na}^{+}$ & $\mathrm{mg} / \mathrm{L}$ & 80.44 & 80.31 & 80.20 & 80.17 & 81.91 & 81.76 & 81.66 & 81.58 \\
\hline 5 & $\mathrm{~Pb}^{2+}$ & $\mathrm{mg} / \mathrm{L}$ & 0.295 & 0.290 & 0.290 & 0.280 & 0.300 & 0.295 & 0.285 & 0.265 \\
\hline 6 & $\mathrm{Cd}^{2+}$ & $\mathrm{mg} / \mathrm{L}$ & 0.090 & 0.085 & 0.085 & 0.080 & 0.075 & 0.075 & 0.075 & 0.075 \\
\hline 7 & $P$ & $\mathrm{mg} / \mathrm{L}$ & 0.675 & 0.665 & 0.665 & 0.660 & 0.670 & 0.660 & 0.645 & 0.635 \\
\hline 8 & $\mathrm{CO}_{3}{ }^{2-}$ & $\mathrm{mg} / \mathrm{L}$ & 3.760 & 3.750 & 3.745 & 3.625 & 3.690 & 3.665 & 3.725 & 3.705 \\
\hline 9 & $\mathrm{SO}_{4}{ }^{2-}$ & $\mathrm{mg} / \mathrm{L}$ & 52.38 & 51.75 & 51.25 & 50.81 & 47.80 & 47.67 & 47.50 & 43.38 \\
\hline 10 & $\left(\mathrm{NO}_{3}^{-}\right)$ & $\mathrm{mg} / \mathrm{L}$ & 40.89 & 40.82 & 40.80 & 40.64 & 42.73 & 42.57 & 42.00 & 41.91 \\
\hline 11 & $\mathrm{Cl}^{-}$ & $\mathrm{mg} / \mathrm{L}$ & 75.40 & 74.01 & 73.67 & 73.26 & 74.67 & 74.54 & 74.44 & 74.36 \\
\hline 12 & $\mathrm{pH}$ & & 7.46 & 7.45 & 7.44 & 7.43 & 7.36 & 7.36 & 7.35 & 7.33 \\
\hline 13 & EC & $\mu \mathrm{S} / \mathrm{cm}$ & 185.5 & 165.0 & 167.0 & 171.0 & 186.0 & 184.5 & 182.0 & 179.5 \\
\hline 14 & BOD & $\mathrm{mg} / \mathrm{L}$ & 69.10 & 67.20 & 66.30 & 66.0 & 66.20 & 64.80 & 65.40 & 64.73 \\
\hline 15 & COD & $\mathrm{mg} / \mathrm{L}$ & 3.225 & 3.120 & 3.060 & 2.990 & 3.100 & 3.050 & 3.075 & 3.455 \\
\hline 16 & Viscosity & & 1.825 & 1.830 & 1.815 & 1.810 & 1.815 & 1.810 & 1.810 & 1.805 \\
\hline
\end{tabular}

\section{Appendix 2}

Chemical properties of water treated with $443 \mathrm{G}$ magnetic flux density

\begin{tabular}{|c|c|c|c|c|c|c|c|c|c|c|}
\hline \multirow{2}{*}{ S/No } & \multirow{2}{*}{ Element } & \multirow{2}{*}{ Unit } & \multicolumn{4}{|c|}{ Magnetic treated water } & \multicolumn{4}{|c|}{ Non-magnetic treated water } \\
\hline & & & Day 1 & Day 2 & Day 3 & Day 4 & Day 1 & Day 2 & Day 3 & Day 4 \\
\hline 1 & 2 & 3 & 4 & 5 & 6 & 7 & 8 & 9 & 10 & 11 \\
\hline 1 & $\mathrm{Ca}^{2+}$ & $\mathrm{mg} / \mathrm{L}$ & 3.140 & 3.110 & 3.100 & 3.100 & 3.130 & 3.095 & 3.055 & 3.020 \\
\hline 2 & $\mathrm{Mg}^{2+}$ & $\mathrm{mg} / \mathrm{L}$ & 1.135 & 1.125 & 1.115 & 1.095 & 1.285 & 1.265 & 1.255 & 1.245 \\
\hline 3 & $\mathrm{~K}^{+}$ & $\mathrm{mg} / \mathrm{L}$ & 0.905 & 0.865 & 0.860 & 0.845 & 0.885 & 0.870 & 0.855 & 0.825 \\
\hline 4 & $\mathrm{Na}^{+}$ & $\mathrm{mg} / \mathrm{L}$ & 80.73 & 80.68 & 80.55 & 80.41 & 81.91 & 81.76 & 81.66 & 81.58 \\
\hline 5 & $\mathrm{~Pb}^{2+}$ & $\mathrm{mg} / \mathrm{L}$ & 0.310 & 0.295 & 0.290 & 0.280 & 0.300 & 0.295 & 0.285 & 0.265 \\
\hline 6 & $\mathrm{Cd}^{2+}$ & $\mathrm{mg} / \mathrm{L}$ & 0.090 & 0.080 & 0.090 & 0.075 & 0.075 & 0.075 & 0.075 & 0.075 \\
\hline 7 & $P$ & $\mathrm{mg} / \mathrm{L}$ & 0.665 & 0.650 & 0.645 & 0.635 & 0.670 & 0.660 & 0.645 & 0.635 \\
\hline 8 & $\mathrm{CO}_{3}{ }^{2-}$ & $\mathrm{mg} / \mathrm{L}$ & 3.580 & 3.520 & 3.505 & 3.505 & 3.690 & 3.665 & 3.725 & 3.705 \\
\hline 9 & $\mathrm{SO}_{4}^{2-}$ & $\mathrm{mg} / \mathrm{L}$ & 51.20 & 50.50 & 49.65 & 48.98 & 47.80 & 47.67 & 47.50 & 43.38 \\
\hline 10 & $\mathrm{~N}\left(\mathrm{NO}_{3}^{-}\right)$ & $\mathrm{mg} / \mathrm{L}$ & 43.91 & 44.13 & 43.05 & 43.01 & 42.73 & 42.57 & 42.00 & 41.91 \\
\hline 11 & $\mathrm{Cl}^{-}$ & $\mathrm{mg} / \mathrm{l}$ & 71.07 & 70.05 & 69.53 & 69.00 & 74.67 & 74.54 & 74.44 & 74.36 \\
\hline 12 & $\mathrm{pH}$ & & 7.41 & 7.41 & 7.40 & 7.42 & 7.36 & 7.36 & 7.35 & 7.33 \\
\hline 13 & EC & $\mu \mathrm{S} / \mathrm{cm}$ & 182.5 & 169.5 & 165.0 & 158.0 & 186.0 & 184.5 & 182.0 & 179.5 \\
\hline 14 & BOD & $\mathrm{mg} / \mathrm{L}$ & 68.59 & 68.15 & 68.41 & 68.00 & 66.20 & 64.80 & 65.40 & 64.73 \\
\hline 15 & COD & $\mathrm{mg} / \mathrm{L}$ & 3.275 & 3.190 & 3.05 & 3.000 & 3.100 & 3.050 & 3.075 & 3.455 \\
\hline 16 & Viscosity & & 1.815 & 1.800 & 1.810 & 1.805 & 1.815 & 1.810 & 1.810 & 1.805 \\
\hline
\end{tabular}




\section{Appendix 3}

Chemical properties of water treated with $319 \mathrm{G}$ magnetic flux density

\begin{tabular}{|c|c|c|c|c|c|c|c|c|c|c|}
\hline \multirow{2}{*}{ S/No } & \multirow{2}{*}{ Element } & \multirow{2}{*}{ Unit } & \multicolumn{4}{|c|}{ Magnetic treated water } & \multicolumn{4}{|c|}{ Non-magnetic treated water } \\
\hline & & & Day 1 & Day 2 & Day 3 & Day 4 & Day 1 & Day 2 & Day 3 & Day 4 \\
\hline 1 & 2 & 3 & 4 & 5 & 6 & 7 & 8 & 9 & 10 & 11 \\
\hline 1 & $\mathrm{Ca}^{2+}$ & $\mathrm{mg} / \mathrm{L}$ & 3.195 & 3.180 & 3.155 & 3.130 & 3.130 & 3.095 & 3.055 & 3.020 \\
\hline 2 & $\mathrm{Mg}^{2+}$ & $\mathrm{mg} / \mathrm{L}$ & 1.355 & 1.340 & 1.320 & 1.285 & 1.285 & 1.265 & 1.255 & 1.245 \\
\hline 3 & $\mathrm{~K}^{+}$ & $\mathrm{mg} / \mathrm{L}$ & 0.890 & 0.875 & 0.860 & 0.825 & 0.885 & 0.870 & 0.855 & 0.825 \\
\hline 4 & $\mathrm{Na}^{+}$ & $\mathrm{mg} / \mathrm{L}$ & 80.93 & 80.84 & 80.63 & 80.40 & 81.91 & 81.76 & 81.66 & 81.58 \\
\hline 5 & $\mathrm{~Pb}^{2+}$ & $\mathrm{mg} / \mathrm{L}$ & 0.285 & 0.275 & 0.270 & 0.255 & 0.300 & 0.295 & 0.285 & 0.265 \\
\hline 6 & $\mathrm{Cd}^{2+}$ & $\mathrm{mg} / \mathrm{L}$ & 0.850 & 0.075 & 0.075 & 0.065 & 0.075 & 0.075 & 0.075 & 0.075 \\
\hline 7 & $\mathrm{P}$ & $\mathrm{mg} / \mathrm{L}$ & 0.650 & 0.630 & 0.620 & 0.600 & 0.670 & 0.660 & 0.645 & 0.635 \\
\hline 8 & $\mathrm{CO}_{3}{ }^{2-}$ & $\mathrm{mg} / \mathrm{L}$ & 3.960 & 3.845 & 3.660 & 3.530 & 3.690 & 3.665 & 3.725 & 3.705 \\
\hline 9 & $\mathrm{SO}_{4}^{2-}$ & $\mathrm{mg} / \mathrm{L}$ & 49.14 & 49.05 & 48.83 & 47.63 & 47.80 & 47.67 & 47.50 & 43.38 \\
\hline 10 & $\mathrm{~N}\left(\mathrm{NO}_{3}^{-}\right)$ & $\mathrm{mg} / \mathrm{L}$ & 42.99 & 42.85 & 42.76 & 42.50 & 42.73 & 42.57 & 42.00 & 41.91 \\
\hline 11 & $\mathrm{Cl}^{-}$ & $\mathrm{mg} / \mathrm{L}$ & 77.38 & 77.23 & 77.18 & 77.05 & 74.67 & 74.54 & 74.44 & 74.36 \\
\hline 12 & $\mathrm{pH}$ & & 7.46 & 7.45 & 7.44 & 7.44 & 7.36 & 7.36 & 7.35 & 7.33 \\
\hline 13 & EC & $\mu \mathrm{S} / \mathrm{cm}$ & 186.5 & 181.0 & 181.5 & 174.5 & 186.0 & 184.5 & 182.0 & 179.5 \\
\hline 14 & BOD & $\mathrm{mg} / \mathrm{L}$ & 58.08 & 57.65 & 57.53 & 56.70 & 66.20 & 64.80 & 65.40 & 64.73 \\
\hline 15 & COD & $\mathrm{mg} / \mathrm{L}$ & 3.275 & 3.170 & 3.300 & 3.075 & 3.100 & 3.050 & 3.075 & 3.455 \\
\hline 16 & Viscosity & & 1.730 & 1.725 & 1.730 & 1.720 & 1.815 & 1.810 & 1.810 & 1.805 \\
\hline
\end{tabular}

\section{Appendix 4}

Chemical properties of water treated with $124 \mathrm{G}$ magnetic flux density

\begin{tabular}{|c|c|c|c|c|c|c|c|c|c|c|}
\hline \multirow{2}{*}{ S/No } & \multirow{2}{*}{ Element } & \multirow{2}{*}{ Unit } & \multicolumn{4}{|c|}{ Magnetic treated water } & \multicolumn{4}{|c|}{ Non-magnetic treated water } \\
\hline & & & Day 1 & Day 2 & Day 3 & Day 4 & Day 1 & Day 2 & Day 3 & Day 4 \\
\hline 1 & 2 & 3 & 4 & 5 & 6 & 7 & 8 & 9 & 10 & 11 \\
\hline 1 & $\mathrm{Ca}^{2+}$ & $\mathrm{mg} / \mathrm{L}$ & 3.300 & 3.240 & 3.150 & 3.060 & 3.130 & 3.095 & 3.055 & 3.020 \\
\hline 2 & $\mathrm{Mg}^{2+}$ & $\mathrm{mg} / \mathrm{L}$ & 1.300 & 1.290 & 1.275 & 1.265 & 1.285 & 1.265 & 1.255 & 1.245 \\
\hline 3 & $\mathrm{~K}^{+}$ & $\mathrm{mg} / \mathrm{L}$ & 0.850 & 0.825 & 0.825 & 0.800 & 0.885 & 0.870 & 0.855 & 0.825 \\
\hline 4 & $\mathrm{Na}^{+}$ & $\mathrm{mg} / \mathrm{L}$ & 80.10 & 79.84 & 79.73 & 79.56 & 81.91 & 81.76 & 81.66 & 81.58 \\
\hline 5 & $\mathrm{~Pb}^{2+}$ & $\mathrm{mg} / \mathrm{L}$ & 0.310 & 0.305 & 0.295 & 0.285 & 0.300 & 0.295 & 0.285 & 0.265 \\
\hline 6 & $\mathrm{Cd}^{2+}$ & $\mathrm{mg} / \mathrm{L}$ & 0.085 & 0.080 & 0.075 & 0.070 & 0.075 & 0.075 & 0.075 & 0.075 \\
\hline 7 & $P$ & $\mathrm{mg} / \mathrm{L}$ & 0.625 & 0.615 & 0.600 & 0.585 & 0.670 & 0.660 & 0.645 & 0.635 \\
\hline 8 & $\mathrm{CO}_{3}{ }^{2-}$ & $\mathrm{mg} / \mathrm{L}$ & 3.300 & 3.240 & 3.155 & 3.140 & 3.690 & 3.665 & 3.725 & 3.705 \\
\hline 9 & $\mathrm{SO}_{4}^{2-}$ & $\mathrm{mg} / \mathrm{L}$ & 47.53 & 47.38 & 47.23 & 47,23 & 47.80 & 47.67 & 47.50 & 43.38 \\
\hline 10 & $\mathrm{~N}\left(\mathrm{NO}_{3}^{-}{ }^{-}\right)$ & $\mathrm{mg} / \mathrm{L}$ & 44.50 & 44.35 & 44.20 & 44.08 & 42.73 & 42.57 & 42.00 & 41.91 \\
\hline 11 & $\mathrm{Cl}^{-}$ & $\mathrm{mg} / \mathrm{L}$ & 75.60 & 75.40 & 75.25 & 75.15 & 74.67 & 74.54 & 74.44 & 74.36 \\
\hline 12 & $\mathrm{pH}$ & & 7.43 & 7.42 & 7.49 & 7.40 & 7.36 & 7.36 & 7.35 & 7.33 \\
\hline 13 & EC & $\mu \mathrm{S} / \mathrm{cm}$ & 177.0 & 175.0 & 173.5 & 171.5 & 186.0 & 184.5 & 182.0 & 179.5 \\
\hline 14 & BOD & $\mathrm{mg} / \mathrm{L}$ & 49.27 & 49.15 & 49.03 & 48.98 & 66.20 & 64.80 & 65.40 & 64.73 \\
\hline 15 & COD & $\mathrm{mg} / \mathrm{L}$ & 3.125 & 3.100 & 3.075 & 3.035 & 3.100 & 3.050 & 3.075 & 3.455 \\
\hline 16 & Viscosity & & 1.720 & 1.715 & 1.705 & 1.705 & 1.815 & 1.810 & 1.810 & 1.805 \\
\hline
\end{tabular}




\section{Nepakankamo drékinimo poveikis pomidorų (Solanum lycopersicum) augimui, drékinant magnetizuotu vandeniu}

\section{Ayodele Olanrewaju Ogunlela, Kamorudeen Olaniyi Yusuf}

Ilorino universitetas, Žemès ūkio ir biologinių sistemų inžinerijos katedra, Nigerija

Šis tyrimas buvo atliktas siekiant nustatyti nepakankamo drekinimo poveiki vegetatyviniam pomidoru (Solanum lycopersicum) auginimui ir derliui. Drekkinama buvo magnetizuotu vandeniu, kuriam magnetinis laukas sukuriamas elektromagnetu. Magnetinio srauto tankis, naudojamas drékinimo vandens apdorojimui, siekè 719G. Pomidoru daigai (veisle UC82B), po 26 dienu daiginimo periodo, buvo persodinti $i$ 16 kibirèliu (1 pomidoru daigas vienam kibirui). Pomidorai buvo auginami po skaidriu sodo stogu dar 94 dienas ir drèkinami magnetiškai apdorotu vandeniu. Kontrolinis eksperimentas taip pat buvo vykdomas su 16 kibirèliu (1 pomidoro daigas vienam kibirèliui) ir drèkinama ne magnetizuotu vandeniu. Šio tyrimo metu pomidoru augalai buvo drekinami 100\%,80\%,60\% ir 50\% vandens poreikio (kai 1,3 litro priskiriama 100\%). Atititinkamai buvo pažymèti keturi eksperimentai - T1, T2, T3 ir T4. Pomidoru aukštis su magnetizuotu vandeniu po 50 dienų buvo atitinkamai $628,8 \mathrm{~mm}, 630,0 \mathrm{~mm}, 600,0 \mathrm{~mm}$ ir $562,6 \mathrm{~mm}$, o pamidoru derlius po 130 dienų buvo $587,8 \mathrm{~g}, 441,9 \mathrm{~g}, 410,7 \mathrm{~g}$ ir $312,4 \mathrm{~g}$ iš vieno pomidoru daigo. Pomidoru daigu aukštis be magnetizuoto vandens buvo atitinkamai $601,3 \mathrm{~mm}, 578,8 \mathrm{~mm}, 557,5 \mathrm{~mm}$ ir $447,5 \mathrm{~mm}$, o T1, T2, T3 ir T4 derlius buvo 439,9 g, 379,5 g, 374,6 g ir 236,6 g iš vieno pomidoru daigo. Derliaus išeiga su magnetizuotu vandeniu padidejo nuo $9,64 \%$ iki 33,62\%, lyginant su nemagnetizuoto vandens išeiga, o magnetizuoto vandens poveikis pomidorų derliui buvo statistiškai reikšmingas.

Raktiniai žodžiai: drèkinimo trūkumas, magnetizuotas vanduo, pomidorai 